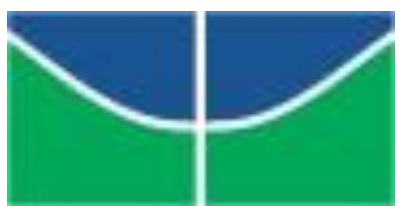

Universidade de Brasília

Faculdade de Educação

Programa de Pós-Graduação em Educação

Áreas livres: um estudo de percepção dos professores sobre as áreas verdes do entorno predial escolar

João Fernando Pereira Filho

Brasília/DF

2016 


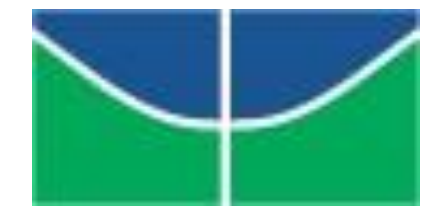

Universidade de Brasília

Faculdade de Educação

Programa de Pós-Graduação em Educação

Áreas livres: um estudo de percepção dos professores sobre as áreas verdes do entorno predial escolar

João Fernando Pereira Filho

Dissertação apresentada ao Programa de Pós-Graduação em Educação da Faculdade de Educação da Universidade de Brasília FE/UnB como parte dos requisitos para a obtenção do título de Mestre. 
João Fernando Pereira Filho

\section{ÁREAS LIVRES: UM ESTUDO DE PERCEPÇÃO DOS PROFESSORES SOBRE AS ÁREAS VERDES DO ENTORNO PREDIAL ESCOLAR}

Dissertação apresentada ao Programa de Pós-Graduação em Educação da Faculdade de Educação da Universidade de Brasília $\mathrm{FE} / \mathrm{UnB}$ como requisito para a obtenção do título de Mestre em Educação, na linha de pesquisa em Educação Ambiental e Educação do Campo - EAEC, sob orientação da Professora Doutora Claudia Marcia Lyra Pato, defendida em 3 de março de 2016. 


\section{ÁREAS LIVRES: UM ESTUDO DE PERCEPÇÃO DOS PROFESSORES SOBRE AS ÁREAS VERDES DO ENTORNO PREDIAL ESCOLAR}

Banca Examinadora:

\section{Professora Doutora Claudia Marcia Lyra Pato}

Orientadora

Faculdade de Educação - FE

Universidade de Brasília - UnB
Professora Izabel Cristina Bruno Bacellar Zaneti
Centro de Desenvolvimento Sustentável - CDS
Universidade de Brasília - UnB

Professora Doutora Claudia Valeria de Assis Dansa

Faculdade de Educação - FE

Universidade de Brasília - UnB

\section{Professora Doutora Leila Chalub}

Faculdade de Educação - FE

Universidade de Brasília - UnB 
Um Salve! a São Francisco. Um Salve!, em especial, a três mulheres: mãe, esposa, orientadora. Um Salve! a muito mais gente. Oxóssi, 'dansa' a todos! 


\section{RESUMO}

Apresento, neste trabalho, um estudo sobre a percepção dos professores de uma escola pública de São Paulo sobre as áreas não construídas no entorno predial. No quadro teórico, utilizei uma literatura que reúne referenciais de áreas verdes escolares em sentido e uso de espaço pedagógico bem como estudos de percepção ambiental na linha de trabalho pessoa-ambiente. O objetivo foi compreender como os professores percebiam essa área no que tange ao potencial pedagógico. A pesquisa foi realizada com seis sujeitos do sexo feminino, entre 34 e 58 anos de idade, média de 11,1 em docência, sendo 3,6 na unidade escolar, representando os períodos matutino e vespertino nas três áreas do conhecimento: Ciências Humanas, Ciências da Natureza e Código e Linguagem. Foram realizadas entrevistas qualitativas a partir de caminhadas com os professores pelo ambiente, para que expusessem diferenças e semelhanças nas preferências e nos desejos, sensações e sugestões de usos em relação à área verde. Esses dados serviram para a construção de mapas perceptivos que mostraram as áreas externas como ambiente de pouca frequência de uso pelos professores, retratando que, apesar da grande extensão, a área livre escolar ainda é pouco utilizada como espaço pedagógico, embora alguns setores tenham aparecido como foco de desejo. Isso, de fato, aponta para a necessidade de aprofundamento na percepção e compreensão de que a área verde melhora o desempenho cognitivo da criança devido ao conjunto diversificado de elementos que a natureza propicia de forma complementar ao ensino-aprendizado indoor.

Palavras-chave: educação, ambiente, professores, áreas verdes, espaços pedagógicos, percepção ambiental. 


\section{RESUMEN}

Que presento en este trabajo, un estudio sobre la percepción de los profesores de una escuela pública en San Pablo en las áreas no incorporadas a la construcción. En el marco teórico, he usado una referencia bibliográfica que reúne a las áreas verdes de la escuela en el significado y el uso del espacio educativo y estudios de percepción del medio ambiente en la línea de persona ambiente. El objetivo era comprender cómo los profesores perciben esta área en relación con el potencial pedagógico. La encuesta se llevó a cabo seis sujetos de sexo femenino, entre 34 y 58 años, promedio 11.1 en la enseñanza, siendo 3,6 en las escuelas, en representación de la mañana y por la tarde en las tres áreas de conocimiento: Humanidades, Ciencias de la Naturaleza y el Código y el Lenguaje. Las entrevistas cualitativas se llevaron a cabo desde el senderismo con los maestros para el medio ambiente, para exponer las similitudes y diferencias en las preferencias y deseos, sensaciones y usos de sugerencias en relación a la zona verde. Estos datos se utilizaron para la construcción de mapas perceptuales que mostraron las zonas exteriores como el medio ambiente utilizan con poca frecuencia por los profesores, que retrata a que a pesar de la gran extensión, la zona escolar libre no es ampliamente utilizado como espacio de enseñanza, aunque algunos sectores han surgido como yo deseo de concentrarse. Esto, de hecho, apunta a la necesidad de profundizar en la percepción y comprensión de la zona verde mejora el rendimiento cognitivo de los niños debido a la diversa conjunto de elementos que ofrece la naturaleza complementaria de la cubierta de enseñanza-aprendizaje.

Palabras clave: educación, medio ambiente, de los profesores, zonas verdes, áreas educativas, de sensibilización ambiental. 


\section{SUMÁRIO}

INTRODUÇÃ

1 REFERENCIAL TEÓRICO ................................................................................12

1.1 AS ÁREAS LIVRES VERDES ESCOLARES: BREVE HISTÓRICO ..........12

1.2 A ÁREA LIVRE ESCOLAR COMO ESPAÇO EDUCATIVO .......................16

1.3 A PERCEPÇÃO DO AMBIENTE ESCOLAR NA EDUCAÇÃO....................21

1.4 A EDUCAÇÃO AMBIENTAL ESCOLAR ……………………………........25

1.5 A RELAÇÃO PESSOA-AMBIENTE.............................................................. 32

2 OBJETIVOS ..............................................................................................................36

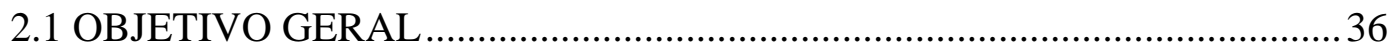

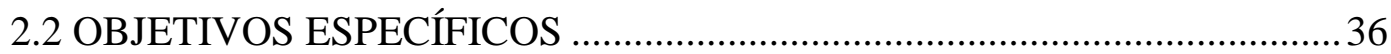

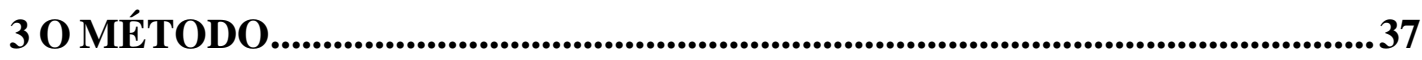

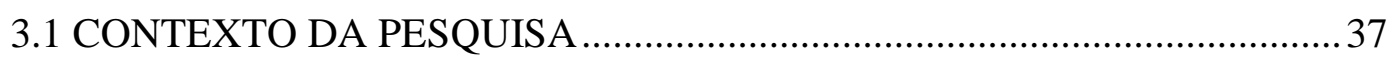

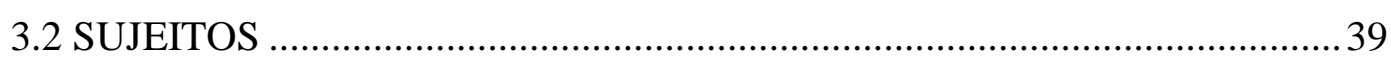

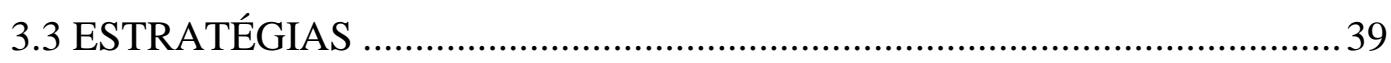

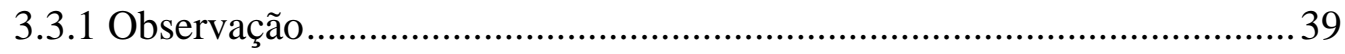

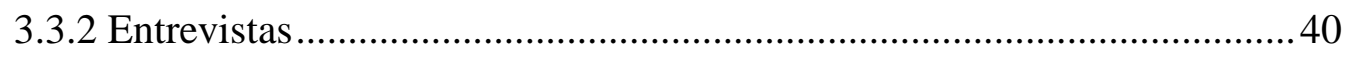

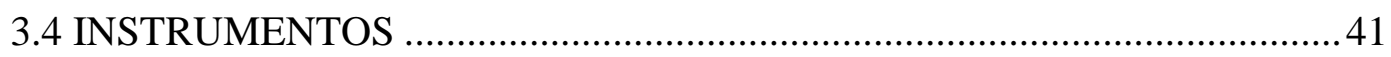

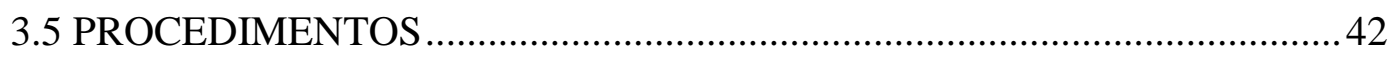

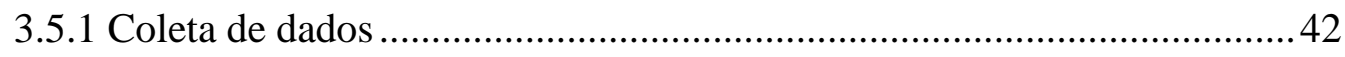

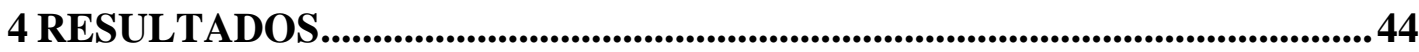

4.1. PERFIL DOS PARTICIPANTES ………………………………………...... 44

4.2 RETRATO DO AMBIENTE A PARTIR DA OBSERVAÇÃO DOS VESTÍGIOS, OCUPAÇÃO E USO - ESCOLA ESTADUAL PROFESSORA

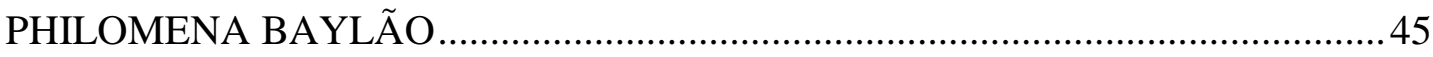

4.3 A PERCEPÇÃO DOCENTES A PARTIR DAS ENTREVISTAS .................47

4.3. 1 A organização do ambiente em setores e as percepções docentes ...........47

5 DISCUSSÃO

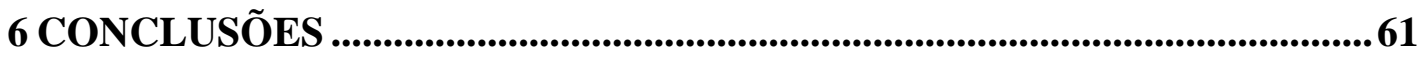

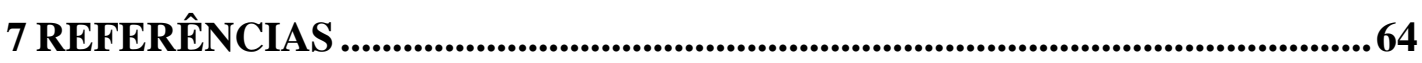

APÊNDICE...................................................................................................... 70

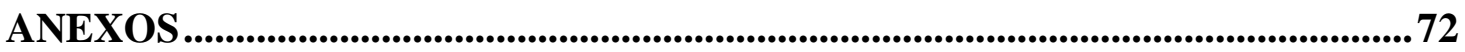




\title{
INTRODUÇÃO
}

\author{
Os olhos lá no Jaraguá \\ Assistirão ao que há de vir, \\ O joelho na Universidade, \\ Saudade... \\ (Paulicéia Desvairada, Mário de Andrade)
}

As observações naturalísticas que registram os aspectos efetivamente manifestos do comportamento humano nos ambientes são utilizadas in loco em pesquisa quando há necessidade de se obter informações referentes à percepção dos sujeitos em relação ao seu ambiente. Isso também foi utilizado na investigação sobre percepção dos professores em área verde livre de uma escola estadual na capital paulista.

Durante seis meses atuando como Professor Coordenador em Oficina Pedagógica de Geografia, na Diretoria de Ensino Norte-2, da Secretaria Estadual de Educação de São Paulo, capital, constatei, por observação em visita, que a maioria das 71 escolas de zêlo e abrangência apresentavam suas áreas verdes cercadas, gradeadas, muradas, sem acesso, uso ou qualquer função pedagógica.

Procurando em (aportes pedagógicos) estudos que abordam as áreas verdes livres escolares, percebi que havia escassez, fragmentação e deficiência de pesquisa na perspectiva do processo ensino-aprendizagem como: a história de surgimento, o uso educativo, o papel de educador(a) ambiental e a percepção que se tem delas.

Assim, surge esta pesquisa de mestrado em Educação, como forma de investigar e compreender a percepção dos professores sobre os espaços verdes escolares como possíveis lugares de aprendizagem.

Neste trabalho, busquei a contribuição teórica de três diferentes grupos. O primeiro grupo critica os sistemas fechados de ensino que facilitam o controle disciplinar, afastando o contato das áreas livres, como: Frago e Escolano (1998), Kowaltowski (2011) e Lima (1989; o segundo grupo, formado por autores como Castellar (2012), Froebel (2001), Gadotti (2008) Tiriba (2008), Sato (2005),Waldorf (apud CARVALHO, 2008), precursores em relacionar as áreas externas livres escolares, o além-sala de aula, como importante aporte pedagógico; e o terceiro, preocupado com a percepção do sujeito com o ambiente, tendo autores como Gibson (1974), Günther (2008), Linch (2014), Rio (1996) e Tuan(2012).

Desde as décadas de 1970 e 1980, com a explosão demográfica na capital paulista, o aproveitamento das áreas verdes das escolas estaduais vem apresentando uma redução em 
sua capacidade de intensificar, diversificar ou mesmo fomentar situações perceptíveis de práticas pedagógicas devido a uma "política de construção de salas de aula". Naquele momento, ocorria um grande movimento migratório para São Paulo e, concomitante, a obrigatoriedade do ensino: acesso e universalização. Os prazos políticos e o clientelismo impuseram a construção rápida em modelos fechados: salas de aula por barreiras, cercas, muros e grades. Uma separação fortificada, reduzindo, ou mesmo banindo, as áreas livres verdes ao uso do cotidiano escolar. Em contra resposta a esse cenário, diversos autores mostram que o ambiente externo é importante para melhor interpretação das sensações, estimulando o desenvolvimento humano na cognição ambiental. Assim, surgem os espaços livres verdes em escolas, hospitais, hospícios e jardins de infância. Áreas de escape que diversificam práticas do cotidiano didático indoor, sem fronteiras rígidas, e que fortalecem uma pedagogia ambiental.

As escolas da cidade de São Paulo, com suas áreas verdes, tornam-se uma das maiores guardiãs do ambiental urbano. Isso destaca, além de seu valor na qualidade de vida da população, o seu fortalecimento como território em educação ambiental, enquanto função educativa a oferecer. Em algumas localidades da urbe, a escola constitui o único equipamento social para o lazer ou práticas culturais da população do seu entorno.

Para melhor compreensão e aproveitamento de leitura, foi necessário pautar definições e derivaçõos de áreas internas e externas, de espaços livres, de espaços abertos e espaços fechados às percepções dos atores envolvidos na pesquisa - os professores. A esses, dá-se o crédito de uma definição em face do conhecimento do chão escola. Valorização do senso comum na capacidade mental de desenvolver um produto de percepção. O entendimento e a definição perceptíveis do espaço escolar.

$\mathrm{Na}$ perspectiva dos sujeitos pesquisados, as áreas escolares dividem-se em interna e externa. As áreas internas - espaços fechados ou ambientes internos, como também é dito, são - corredores, hall de distribuição e conexões de mobilidade discentes, salas de aula, suportes pedagógicos e administrativos e o de recreação: pátios internos. As áreas externas subdividem-se em duas partes: áreas de espaços abertos, quadras e estacionamento; área livre verde, que compreende a maior parte circundante do prédio escolar e dos espaços abertos, franja verde escolar que borda com ruas e calçadas da urbe.

Esta pesquisa procurou identificar, a partir dos elementos fornecidos pelos professores, como se constrói a percepção deste grupo sobre as áreas verdes do entorno predial escolar e seu entendimento dessas áreas como possível espaço educativo. 
Este trabalho é dividido em cinco capítulos.

O capítulo 1 traz no referencial teórico a contextualização histórica e o surgimento da área verde escolar no resgate como espaço educativo, ao estímulo e uso pedagógico em percepção do ambiente escolar na Educação Ambiental que amplia práticas didáticas indoor ao investigar a abordagem 'pessoa-ambiente escolar'.

Os capítulos 2 e 3 trazem os objeitvos e a metodológica, respectivamente, e os 4, 5 e 6 tratam dos resultados e da discussão da pesquisa bem como das conclusões e dos apontamentos para o futuro. 


\section{REFERENCIAL TEÓRICO}

\subsection{AS ÁREAS LIVRES VERDES ESCOLARES: BREVE HISTÓRICO}

Em São Paulo, capital, o espaço livre escolar surgiu a partir dos colégios jesuítas. Essas áreas de entorno predial foram cercadas ou amuralhadas, e a tomada de decisão quanto ao uso e à função era de incumbência dos priores, com a participação dos internos. Hortas, pomares e jardins eram o destino da maioria dessas áreas. Entretanto, após meados do século XX, as áreas externas livres verdes e os prédios escolares abandonaram os estilos europeus durante a República Velha, os Liceus (RONDON, 2014), e passaram a ter outra motivação arquitetônica em face do boom migracional, da universalização do ensino e da democratização da educação.

Na construção de escolas para atender a essa explosão urbana, a Secretaria Estadual da Educação de São Paulo encontrou facilidade e rapidez: o concreto armado em forma de cubos. De 1960 a 2004, foram mais de 5 mil escolas construídas para suprir vagas no ensino público devido à demanda sempre crescente, especialmente na capital paulista (FDE, 2006, p. 16).

Análise em pranchamentos arquitetônicos no acervo das escolas paulistas, um dos poucos existentes em consulta na metrópole, revela que, com a estandardização predial escolar, as concepções paisagísticas em generosos espaços livres não construídos do entorno predial foram suprimidas dos projetos (FDE, 2006).

Segundo o Ministério da Educação - MEC, no Referencial Curricular Nacional para Educação Infantil - RCNEI, "aos espaços externos, estes deverão ser lúdicos e alternativos que permitam que as crianças corram, balancem e joguem etc.”. O paisagismo externo deve possuir áreas de encontro de descanso e que permitam o isolamento da criança quando esta sentir necessidade de ficar sozinha. Esses locais devem, antes de tudo, despertar na criança curiosidade para que ela possa explorá-los e, com isso, aprender por meio de descobertas, apropriações e realizações dentro desses espaços (MEC, 2006).

Conceituando as áreas e ou espaços ao ar livre em centro de atendimento escolar por aluno, o Índice de Área Verde Escolar - Iave, no Brasil, os autores Callejas, Durante, Oliveira e Nogueira $(2014$, p. 463$)$ afirmam a importância de, pelo menos, $12 \mathrm{~m}^{2} /$ aluno nos ambientes escolares. Nos Estados Unidos e no Canadá, Moore (1996 apud ELALI, 2003) define três categorias de tamanho para áreas verdes escolares: mínimo, $7,5 \mathrm{~m}^{2}$; recomendado $10 \mathrm{~m}^{2}$; e generoso $20 \mathrm{~m}^{2}$. O Ministério da Educação (2006, p. 22) não estabelece critérios, e a única recomendação é que a área livre ocupe $50 \%$ do terreno escolar. Isso reflete o pensamento do movimento Escola Nova, em que a escola não é encarcerada dentro de sua própria estrutura 
interna, prioritariamente na sala de aula, mas em formas de sociabilidade que criam uma nova dinâmica relacional espacial, onde as fronteiras dos espaços fechados e verdes sejam tênues, agregando diversas atividades adequadas às diferentes fases etárias do desenvolvimento de cognição, espaços verdes livres que agregam lugares de estudo ou lazer, de estímulo ao prazer e à recreação,

Nesse cenário, surgem vários autores, em diferentes linhas de abordagem, que consolidam fundamentos conceituais e entrelaçam estudos sobre os espaços escolares com ideário à condição humana de interação social no ensino-aprendizagem, revelando pontos e contrapontos entre as abordagens arquitetônica e pedagógica na contemporaneidade (ELALI, 2003; FREDIZZI, 2002; GADOTTI, 2008; KOWALTOWSKI, 2011; LIMA， 1989; OLIVEIRA, 1998; PRESCOTT, 1987; TIRIBA, 2008).

Os precursores em dar importância pedagógica às áreas externas livres escolares, o além-sala de aula são: Montessori (apud ELALI, 2003), Bernstein (apud MEC, 2006), Waldorf (apud CARVALHO, 2008), Guattari (apud ELALI, 2003), Freire (1994) e Froebel (2001), fundador do primeiro jardim de infância denominado "estabelecimento para o cultivo das disposições naturais da criança e do jovem”, em 1837.

Na década de 1870, na província de São Paulo, criou-se o primeiro jardim de infância, o Colégio Menezes Vieira, tendo em seu manual uma compilação das ideias de Froebel (KISHIMOTO, 1988).

Todos os autores citados orientam qualidade de espaços escolares abertos à interação com a natureza em atividades relacionadas ao fomento de uma ecologia pessoal, social e ambiental, mostrando, nesses espaços, a importância de exigências quanto à percepção pedagógica ambiental. Isso significa que a integração do sujeito com seu meio natural ocorre de forma mais apropriada quando existe na relação de ensino-aprendizagem uma integração entre a pessoa e o ambiente.

Contrariamente a essa corrente, as escolas possuem, na atualidade, constructos em que as edificações mostram as salas de aula tradicionais e as poucas áreas externas existentes sem exploração metodológica. As salas continuam sendo as maiores abrigadoras de práticas pedagógicas em desenvolvimento interno. Um espaço segmentado, no qual o ocultamento das áreas livres e o aprisionamento servem, necessariamente, ao controle da disciplina, lutando contra a visibilidade e a transparência das áreas externas para a vigilância (FRAGO; ESCOLANO, 2001, p. 80).

Esse propósito, em concepção de educação pautada pela coerção e pelo controle social, foi relatado por Lima (1989) quanto às construções das escolas estaduais em São Paulo. 
Segundo a autora, a Companhia de Construções Escolares do Estado de São Paulo, em diferentes governos, faz uma arquitetura com práticas clientelistas, prazos políticos e taxas de lucro dos empreiteiros. Isso levou à redução qualitativa e quantitativa dos espaços externos e à baixa percepção dessas áreas por parte dos profissionais envolvidos (educadores, pedagogos, gestores, arquitetos, engenheiros, paisagistas etc.). A agenda atende ao tempo limítrofe na demanda construtiva. Os resultados foram concepção de projetos arquitetônicos na criação de espaços escolares como meros arranjos de construção sem qualquer preocupação de exigência educativa com paisagens externas

Em consulta sobre arquiteturas escolares entre 1979 a 1982, a Secretaria Estadual de Educação de São Paulo, em conjunto com os Delegados Regionais de Ensino, Supervisores e Diretores, participou de uma ampla análise de planejamento que consistia em 'criar salas de aulas' segundo o critério político de demanda, o clientelismo (LIMA, 1989, p. 68).

Quando o sistema educacional democratizou o acesso e a permanência, as áreas livres foram, aos poucos, suprimidas, passando por um processo de redução de tamanho, de cultura de uso e de circulação devido às barreiras criadas. $\mathrm{O}$ uso de grades, cercas, arames ou muros nos espaços escolares leva à perda das funções ambientais, porém garante, amplia e fortifica os espaços ao atendimento e à permanência do educando; desprezando as áreas externas como espaços que garantem também um atendimento diferenciado e reduzindo a educação indoor, as áreas externas escolares tornam-se relicário ambiental em letargia e esquecimento.

As áreas livres no interior da escola passam por uma forma de apropriação em diferentes contextos. Quanto mais periférica e carente é a comunidade, mais intensifica o processo de emagrecimento, redimensionamento ou mesmo o seu desaparecimento (LIMA, 1989, p. 6.567)

Cria-se uma psicologia espacial simbólica (TUAN, 2013, p. 49), a qual se credita a ideia "centro" e "periferia" na organização espacial em que pessoas e lugares tendem a se estruturarem a partir de forças e valores decrescentes. Em dois polos de eixo vertical, a perspectiva da experiência em estudo espacial simbólico informa que alto e baixo, norte e sul, frente ou atrás são palavras que, na maioria das línguas, transcendem o significado literal. São ideias universais de organização espacial em que as pessoas tendem a estruturar o espaço com elas no centro, partindo de um estado de sentimento de aconchego e indo para o desagradável. Assim são os valores crescentes e decrescentes (TUAN, 2013, p. 52-53). Tudo que é superior ou excelente é elevado, associado a um sentido físico, é excelso, grande, supremo, universal e de crença (Idem, p. 52-53). A arquitetura dos prédios escolares durante a República 'os Liceus' acompanhava esse procedimento, construídos em áreas elevadas do bairro. 
Em 1940, 1,3 milhões de habitantes viviam na capital de São Paulo; em 1980, a população já superava os 8 milhões, alcançando mais de 12 milhões se considerada a região metropolitana (BONDUKI, 2004). Hoje, é estimada em mais de 20 milhões.

O exposto revela pressa nas construções de prédios escolares, mas a pouca verba despendida prejudicou a qualidade arquitetônica em detalhamento para a criação de espaços externos ao uso, numa perspectiva de encontro e fomento em atividades complementares.

As escolas deixam de ser pontos visíveis em áreas centralizadas, elevadas e nobres da cidade, perdem em expressão, para serem construídas em sobras de loteamentos: encostas ou vales, áreas baixas que a legislação destinava ao interesse ambiental. Isso legitimou a presença do homem em território que se contrapõe com os elementos da natureza.

Da centralidade à periferia, fez-se a hierarquização de valores. O sujeito, partindo da centralidade e da esfera de interesse e privilégio, expande do que é visível ao que lhe possa preocupar ou desagradar.

O espaço, assim como o tempo, tem sido tratado em nossas escolas (e, por conseguinte, no Programa Mais Educação), como algo que não é, mas poderia ser. Quase sempre nos referimos a ela pelas faltas, pela negatividade: por não ser adequado, por estar em condições estruturais e ambientais ruins ou por ser muito frio; barulhento, escuro, depredado, feio, sujo, minúsculo, bagunçado ... impossível!! [sic] (MEC, 2014, p. 9).

Vários espaços importantes entram em um processo de racionalização e, para justificar o empobrecimento ou invisibilidade, Lima (1989, p. 38) mostra diálogos em que critica o poder comumente usado. Alegações são de que crianças não precisam de bibliotecas e salões, esses somente servem para reunir os alunos uma vez ao ano; crianças soltas em espaços livres podem se machucar, e assim por diante. São visões sobre as áreas externas escolares que deixaram marcas relevantes, manifestando uma hierarquia de ordem social e espacial.

Esse desenho concebido, dominante e usual, serve de controle. As salas de aula ou os pátios internos respondem sempre ao ideário de clausura e solidez. Com restrições e pouca funcionalidade, a área livre perde como território educativo, de interação social, de uso em situações pedagógicas como lugares possíveis ao ensino-aprendizagem.

Na perspectiva de ensinar tudo a todos, Comenius (1592-1670), 'O Pai da Didática Moderna' aos bons educadores, apercebe que o professor não se faz em sala de aula com método tradicional de ensino, mas é aquele indivíduo que vive seu tempo histórico-social, ou seja; faz registros e, em tempo, leva a uma forma didática adequada em que alunos aprendem sistematizando conhecimento e construindo uma didática que não seja enfadonha, com dispendio de tempo, fadigando e esgotando forças educadoras. Nessa perspectiva, a área verde 
entra como o além-sala de aula, reparador e integrador de espaço de fuga às forças contrárias já expostas historicamente.

\title{
1.2 A ÁREA LIVRE ESCOLAR COMO ESPAÇO EDUCATIVO
}

\author{
"Vais encontrar um mundo, disse-me meu pai, à porta do \\ Ateneu. Coragem para a luta." (Raul Pompeia, O Ateneu).
}

Desde a remota Grécia Antiga, quando se procurava mostrar preocupação com as áreas livres, reconhece-se a importância dessas no cotidiano pessoa-ambiente, tanto para o desenvolvimento cognitivo quanto para a saúde:

\begin{abstract}
[...] outros aspectos da medicina também são importantes aqui. O primeiro deles é que a saúde e a doença são formas de relação entre nosso corpo e o meio ambiente (por isso o médico grego estuda o mundo onde está e onde vive nosso corpo, isto é, as águas, os ventos, os terrenos, os lugares, os astros, os alimentos, as horas do dia e da noite, as estações do ano etc.). Assim é preciso haver, no mínimo, a dualidade homem mundo para que haja a medicina. Em resumo, a medicina não dispensa a experiência sensorial, a percepção e a memória.

Empédocles... era médico e, certamente, as ideias médicas e a prática médica tiveram papel fundamental em cosmologia. (CHAUÍ, 2002, p. 108-109).
\end{abstract}

Porém, foi somente com a Psicologia que surgiram pesquisas centradas sobre a experiência espacial humana; em específico, nas relações humano-ambiental, demonstrando que carências múltiplas podem ser oriundas de privações socioafetivas de contato com o espaço físico cercado por elementos naturais (GARCIA, 1996, p. 25-26).

Modelos pedagógicos que têm como objetivo principal a melhoria no processo de aprendizagem dos indivíduos, por meio da reflexão, sistematização a produção de conhecimento, que limitam o maior tempo do sujeito aprendente à sala de aula, inviabilizam a expansão da esfera socioambiental e contribuem para a inibição da criança, levando-a ao esgotamento excessivo por ter de suportar exigências de transformação comportamental além das possibilidades de seu desenvolvimento.

Isso cria uma separação exclusiva da pessoa em relação ao seu ambiente (CAMPOSDECARVALHO, 2008, p. 15).

[...] desenvolvimento implica em processos através dos quais as propriedades da pessoa e do ambiente interagem, produzindo tanto continuidade quanto mudanças nas características da pessoa durante o curso de vida, no mundo como ela percebe e negocia com seu ambiente, isto é, mudanças e constâncias nas suas capacidades em descobrir, manter ou alterar as propriedades do ambiente, as quais, por sua vez, também exercem influências nas características da pessoa [sic] (BRONFENBRENNER, 1993, 1995 apud CAMPOS-DE-CARVALHO, 2008, p. 14). 
Nessa linha, o MEC (2014), no caderno Territórios Educativos, em que reflete temáticas sobre educação, orienta que as escolas ofereçam espaços externos múltiplos de uso.

[...] desregular o óbvio (e tudo o que nos parece natural), precisamos superar os modelos herdados que nos fazem acreditar que a escola e a cidade são assim mesmo e sempre serão naturalmente. Como primeiro passo, propomos que a gente olhe para este óbvio, este natural, com estranhamento [...] recompor nossos conceitos, derrubar pré-conceitos [sic] e escolher outros a partir dos quais possamos entender que o espaço é muito mais do que parece ser, e pode muito mais do que tem sido considerado por nós, pela escola, pela educação e pela arquitetura (ibid., p. 16).

Uma ordem super-resistente e poderosa que enrijeceu o tempo e o espaço e a nossa percepção sobre eles, de forma que chegamos ao ponto a tomarmos como natural, inquestionável e de impensável a sua modificação, a ponto de dizermos: “[...] os espaços das escolas sempre foram assim. Como poderíamos mudar? E por que mudar? Para que? Escola é assim mesmo (fala de um gestor)" [sic] (ibid., p 11).

Pesquisas que abordam teorias dos espaços escolares são recentes (CARPINTEIRO, 2009, p. 85), pois a edicação escolar é um equipamento novo se comparado a fóruns, igrejas e palácios. Tanto o prédio com suas mobílias quanto as áreas livres externas têm uma necessidade de transformação contínua.

Ao discutir a importância do papel do ambiente no desenvolvimento socioafetivo em território escolar, as relações entre pessoa-ambiente revelam que lugares contribuidores para competências individuais, compreensão ecológica de comportamento e formação da identidade pessoal mostram a necessidade de enfrentar a diferença temporal entre a pedagogia e a arquitetura.

O projeto de escola, seja essa qual for, deve ser elaborado prevendo trabalhos com determinados métodos que não duram para sempre, que ficam obsoletos, que exigem reciclagem, que acontecem com diferentes velocidades de tempo e espaço construídos. Daí a importância de pensar em áreas livres escolares que levam em conta as mutações, tão naturais nas coisas humanas (OLIVEIRA, 1998).

O histórico currículo da educação vê na corrente ambiental sociointeracionista a ação pedagógica no espaço escolar. O sociointeracionismo é uma abordagem que estuda as trocas entre o homem e a realidade em que vive e apresenta o impacto do sujeito sobre o meio físico e social e a confluência na construção do sujeito. No século XX, Jean Piaget desenvolve uma teoria epistemológica, forte e consistente, que aponta a ideia de que o conhecimento não é algo pronto, sendo construído a partir da ação, ou seja, cada sujeito estaria sempre evoluindo na aquisição contínua de seu conhecimento a partir das formas interacionistas. Isto é, o sujeito aprende por meio de suas ações, e ele próprio constrói o conhecimento das interações com o ambiente (CARPIGIANI; MINOZZI, 2000 apud AZEVEDO, 2002, p. 89). 
A pedagogia, por estar ligada à melhoria do processo de aprendizado na formação do sujeito e sistematizando a produção do conhecimento, torna-se vanguardista das práticas de aprendizagem reflexiva entre o homem e a natureza. Em diferentes linhas de abordagem, ela vem contribuindo com fundamentos conceituais que entrelaçam estudos sobre os espaços livres escolares não edificados com o ideário da condição humana de interação social e de ensino-aprendizagem, como contraponto pedagógico ambiental. Temos como exemplo a Pedagogia da Terra (GADOTTI, 2008, p. 74) e a Ecopedagogia (GUTIÉRREZ, 2008).

A Pedagogia da Terra é uma reconstrução paradigmática, apropriada à cultura da sustentabilidade e da paz, que vem se constituindo gradativamente, beneficiando-se de muitas reflexões que ocorreram nas últimas décadas, principalmente no interior do movimento ecológico. Fundamenta-se num paradigma filosófico emergente na Educação, propondo um conjunto de saberes/valores interdependentes: educar para pensar globalmente, educar os sentimentos, ensinar a identidade terrena, formar para a consciência planetária, formar para a compreensão e educar para a simplicidade (GADOTTI, 2008).

São vários os representantes dessas linhas de pensamento, entre eles: Paulo Freire, Leonardo Boff, Sebastião Salgado, Boaventura de Souza Santos, Milton Santos, Aziz Ab`Sáber, Thomas Berry, Fritjop Capra e Edgar Morin (GADOTTI, 2008).

À pedagogia, deve ser conferida mais uma função enriquecedora de ação ao incorporar às áreas livres verdes o seu potencial para práticas em situação de ensino-aprendizagem.

No ato de propor um currículo escolar, deve-se levar em conta que esse pode transformar a escola e, ao construir e cultivar espaços, atentar que o universo não está lá fora, está dentro de nós, à nossa volta (GADOTTI, 2008, p. 78).

[...] um pequeno jardim, uma horta, um pedaço de terra, é um microcosmo de todo o
mundo e, nele, podemos encontrar formas de cultivar, construir e aprender muitas
coisas como. O jardim nos ensina ideais democráticos, conexões, escolhas,
responsabilidade, decisões, iniciativa, igualdade, biodiversidade, cores, classes,
etnicidade e gênero.

Anísio Teixeira (1951) propunha uma "escola com espaço para a comunidade, com equipamentos complementares à educação. Jardins e parques" [sic] ou "nenhum outro elemento é tão fundamental, no complexo da situação educacional, depois do professor, quanto o prédio e suas instalações" [sic].

Montessori (1870-1952), educadora italiana, depois de formada em medicina, iniciou seus trabalhos com crianças e observou que estas ficavam brincando nas ruas e, assim, criou 
espaço educacional pedagógico de aprendizagem. Isso já mostrava preocupações iniciais com os espaços escolares além-sala a serem utilizados.

A teoria do espaço escolar contribui quando analisa as áreas escolares com ênfase didático-pedagógica, vinculando essas áreas atividades e práticas correspondentes de saberes formativos ao sujeito e ampliando a consciência quanto a outros lugares de ensino-aprendizado ou introduzindo noções básicas sobre conhecimento perceptivo do espaço.

Para Carpinteiro (2008, p. 46), a percepção dos espaços escolares somente atua no sujeito caso estabeleça conexões entre as práticas pedagógicas, como brincadeira e ludicidades, envolvendo os elementos naturais na aprendizagem. "A atividade, mais que o ambiente construído, faz do espaço um espaço educativo" [sic] .

No sujeito, a noção de espaço vai sendo construída a partir de sua percepção e manipulação desse espaço; isso ocorre por meio do desenvolvimento dos sentidos e dos movimentos corporais, em que se aprende que o espaço construído surge a partir da interrelação entre o sujeito e o objeto. $\mathrm{O}$ aprofundamento de valores se efetiva quando a percepção do sujeito diante do espaço vence gradativamente a fase egocêntrica diferenciando o "eu” em detrimento ao "coletivo" (TUAN, 2013, p. 67).

Tudo que afasta experiências e ou observações diretas do campo a ser explorado afasta também os valores, entendidos aqui como os ambientais na formação pré-escolar, segundo Piaget (CARPINTEIRO, 2008, p. 25). Nesse sentido, os valores ambientalmente ecológicos estão associados à relação da pessoa com o ambiente e são fundamentais para a compreensão dessa relação (PATO, 2011, p. 296).

Espaços que limitam o movimento do corpo e que fazem parte de estratégias de controle do pensamento foram dialogados por Lima (1989), com base piagetiana. Segundo essa autora, a criança, em determinada fase, passa por um processo cognitivo da aprendizagem, que depende basicamente da percepção do ambiente para elaborar elementos estruturais que permitem pensar a respeito de temas e comportamentos mais complexos.

Pesquisa realizada (LIMA, 1989, p. 44) informa que o lugar de aprender na pré-alfabetização, o espaço escolar, ainda é a sala de aula "as professoras ordenavam que as crianças permanecessem sentadinhas nas carteiras no momento em que as crianças estão fazendo exercícios de controle motor, através de desenhos de minhocas, cobras, ondas" ou "que o lugar de aprender, para os adultos, é a sala de aula e nela procura-se tratar exclusivamente de assuntos previstos na programação".

Contrariamente ao espaço opressor das salas de aula, projetadas pelo adulto, a pesquisa da autora revela algo relativo à percepção do espaço escolar, o apelo e o interesse das áreas 
verdes livres são ainda preferência das crianças (idem, p. 46-48). Assim, Lima (1989), ao observar as restrições do uso dos espaços escolares, afirma que a escola é como uma instituição de característica semelhante às prisões com tecnologia de controle do corpo pelo poder. A escola ainda se contenta com estímulos do saber por meio da sala de aula, os quais são reforçados pela falta de reflexão de estudos para as áreas, é a arquitetura em blocos pedagógico, administrativo e recreativo - revelando espaços escolares panópticos ${ }^{1}$.

Por solicitação dos educadores, as portas possuem visores, simples retângulo de vidros, a altura dos olhos dos adultos, para que o diretor, passando pelo corredor, possa saber o que se passa no interior das classes. A simples possibilidade de serem observadas, sem aviso prévio, faz com que as crianças, contenham seus impulsos, obedecendo assim princípios do panoptismo [sic] (LIMA, 1989, p. 39).

Essa reconquista dos espaços [...] requer o rompimento da escola/prisão/fortaleza e sua transformação na escola/praça/parque (MEC, 2006, p. 24).

No ano seguinte, o Ateneu revelou-se me noutro aspecto. Conhecera-o interessante, com as seduções do que é novo, com as projeções obscuras de perspectiva, desafiando curiosidade e receio; conhecera-o insípido e banal como os mistérios resolvidos, caiado de tédio; conhecia-o agora intolerável como um cárcere, murado de desejos e privações (POMPEIA. 1996, p. 112).

Escolas que apresentam espaços de áreas verdes em redução de uso, não as destinando a potencialidades de práticas de ensino direcionadas ao convívio ou à socialização, são espaços sem identidade e sempre iguais em cores, volumetria e estrutura, que não permitem nenhuma fantasia prazer ou ideia nova (LIMA, 1989, p. 70).

As escolas passam a ter, na maioria, espaços para uso coletivo, os pátios internos, assemelhados aos espaços de controle dos impulsos, de repressão comportamental, dependência e submissão, controles rígidos que efetivamente aproximam o comportamento da criança e do adolescente ao do adulto, punindo os que se afastam desse comportamento (LIMA, 1989, p. 57).

As áreas verdes livres de uma escola precisam ser pensadas com a intenção de deixar o suficiente para estimular a curiosidade e a imaginação da criança e incompletas o bastante para que essa se aproprie e as transforme de acordo com a sua própria ação. O homem altera o espaço, e este, uma vez alterado, altera o homem também.

Atitudes, ação e reflexão são exercícios para explorar incessantemente o meio ambiente e desenvolver impressões visuais que adquirem solidez e profundidade, estão

\footnotetext{
${ }^{1}$ Já Frago e Escolano (1998, p. 79) explicitavam em leitura de Foucault espaço panótico: [...] sobretudo em Vigiar e Punir - caracterizava a escola, limitada a um espaço fechado, junto a outras instituições disciplinares, de dominação e controle, tais como quarteis, hospitais ou cárceres. Seu modelo prévio seriam os conventos. Independentemente da maior ou menor adequação a cada caso concreto [...].
} 
associados ao movimento pessoa-ambiente e objeto. Para Gibson (1974, p. 303), essa é a base de uma teoria da motricidade visual na percepção. Na Educação, a conduta espacial está intimamente ligada à percepção do ambiente escolar.

\subsection{A PERCEPÇÃO DO AMBIENTE ESCOLAR NA EDUCAÇÃO}

La explicación tradicional de la visión e tener sensaciones. Se supone que las sensaciones constituyen la matéria prima de la experiencia humana y que las percepciones son el produto elaborado (GIBSON, 1974, p. 13).

A percepção, do latim perceptivo, é definida como uma combinação dos sentidos no reconhecimento de um estímulo externo. Na definição presente nos dicionários de língua portuguesa, estão incluídas ainda palavras como intuição, imagens, representações ou ideias (KUHNEN, 2011, p. 250). Nesta pesquisa, trabalhei com a percepção ambiental que, segundo Rios (1996), se refere ao processo de interação dos indivíduos com o ambiente, envolvendo mecanismos perceptivos e cognitivos, podendo constituir importante instrumento para a avaliação das práticas e dos fundamentos da educação ambiental, uma vez que permite expor as visões, as imagens e os valores que esses indivíduos desenvolvem a respeito do que os cerca.

O processo de apropriação do espaço ocorre pela interação do sujeito com seu entorno, levando-o a projetar valores e crenças na transformação do prolongamento natural do indivíduo com o lugar. A transformação ocorre a partir da intensidade em que o espaço ou o objeto forçam no sujeito orientações com grau elevado de ações que vão se apropriando por meio da percepção espacial e criando sentimento amplo de lugar. $\mathrm{O}$ apego, o sentimento, o aconchego, a funcionalidade, as necessidades etc., tudo isso acontece não somente pela visão, mas pela forma como essa é afetada pela nossa percepção ambiental (TUAN, 2013 p. 11).

Os processos de percepção são: cognitivos, afetivos e interativos (HIGUCHI; KUHEN; BOMFIM, 2011, p. 107).

A percepção espacial efetiva-se a partir de experiência corporal entre o sujeito e as relações com os objetos e o espaço. Essa construção é gradual e, segundo Piaget, ocorre envolvendo os estímulos recebidos nas trocas entre a pessoa com outros seres vivos e com objetos, levando em conta o tempo em termos de ciclo de vida, infância, adolescência, juventude, fase adulta e terceira idade (Idem, p.107).

A percepção é de fundamental importância no processo cognitivo, pois convida o sujeito a se permitir tomar consciência do entorno a partir do sensório visual. Isso já foi 
estudado no desenvolvimento infantil na fase pré-escolar. As crianças começam a fazer paralelos perceptíveis a partir da visão e vão evoluindo por meio mais complexo com a percepção cognitiva (PIAGET, 1978; VYGOSTSKI, 1998 apud KUHNEN, 2011, p. 252). "Podemos dizer que o desenvolvimento da acuidade visual está relacionado à qualidade ecológica do meio ambiente" (TUAN, 2012, p. 339).

A visão humana, como a de outros primatas, evoluiu em um meio arbóreo, denso e complexo de uma floresta tropical, e, assim, o homem depende mais conscientemente da visão do que dos demais sentidos para progredir no mundo; é um animal essencialmente visual, pois um mundo se abre com mais informações de forma detalhada e especificada por meio dos olhos. Os órgãos dos sentidos a serem exercitados variam de acordo com o indivíduo e sua cultura. Na cultura ocidental, precisamente na sociedade moderna, o campo de inferência visual é maior (TUAN, 2012, p. 22).

Para entender como o sujeito interage e experiencia nos espaços - apropriação, interpretação, construção de significados e de comportamento -, observa-se que a melhor relação de uma compreensão surge na percepção ambiental visual com a combinação dos outros sentidos no estímulo externo dos elementos naturais que rodeia o sujeito (ITTELSON, 1973 apud KUHNEN, 2011, p. 250-251). Cada sentido reforça o outro de modo que juntos estabelecem estruturas perceptíveis ambientais.

A psicologia ambiental inserida nos espaços das unidades de ensino sugere que, na educação ambiental, se promovam relações afetivas, psíquicas e cognitivas ao mesmo tempo em que se assegurem também a individualidade, a coletividade, o compartilhamento e a socialização que os espaços verdes escolares podem oferecer. Para que isso ocorra, o sujeito terá de encontrar condições de espaços escolares permeáveis na possibilidade de ações que envolvam um entendimento geral de cognição ambiental; em que o repertório de conhecimento cognitivo pelo sujeito acerca do ambiente e seus elementos constituídos sugira ações efetivas a partir da interação. Isso é a topofilia, ou seja, o elo afetivo entre a pessoa e o lugar visível em que as lembranças captam a atenção do sujeito (TUAN, 2013, p. 135).

A capacidade perceptiva da cognição ambiental pode ser entendida como a capacidade humana de conhecer, armazenar e extrair informações de ambientes físicos, sociais e naturais.

Ao processo cognitivo ambiental, soma-se outro, o cognitivo espacial. Nessa junção, ocorre uma integração enriquecedora da aprendizagem porque a cognição espacial predomina na literatura como processo estruturante de aprendizagem em aspectos quantitativos de informações do ambiente; e a cognição ambiental é responsável pela qualidade aprendida, de forma engajada e completa, forma-se no indivíduo mediante o conhecimento adquirido por 
meio de imagens, informações, impressões, crenças, elementos estruturais, funcionais e ou simbólicos com o ambiente. Isso se projeta de forma laboral quando o sujeito envolve mecanismo sensitivo e estimulante com o ambiente (ARAGONÉS, 2002).

$\mathrm{O}$ aspecto geral dos ambientes e suas condições influenciam a percepção dos usuários, o que pode levar ao environmental numbness, ou seja, à apatia causada pelo ambiente físico degradado, criando uma espécie de paralisação no indivíduo (KOWALTOWSKI, 2011, p. 115), interferindo na banalidade para com a paisagem escolar e, ao mesmo tempo, revelando a importância de explorar as áreas verdes como espaços propícios às práticas da aprendizagem além-sala de aula.

Quanto ao tempo, não se deve esquecer que o espaço-escola, como qualquer outro tipo de construção, é uma criação histórico-cultural que está sujeita a mudanças e, mesmo sendo espaço educativo com rituais de conhecimento, é dotado de grandes significados construídos. Assim, o que se pode ter como espaço e lugar é a construção do sujeito em seu pertencimento.

Ao espaço, projeta-se o que se imagina, e o lugar se constrói a partir do fluir da vida cotidiana (FRAGO; ESCOLANO, 1998, p. 61).

\begin{abstract}
A vida cotidiana é, em grande medida, heterogênea, e isso sob vários aspectos, sobretudo no que se refere ao conteúdo e à significação ou importância de nossos tipos de atividade. São partes orgânicas da vida cotidiana: a organização [...] da vida privada, os lazeres e o descanso, atividade social sistematizada, o intercambio e a purificação (HELLER, 2008, p. 32).
\end{abstract}

Frago (1998) salienta que há certa preferência em dividir o aspecto teórico-discursivo na distribuição do espaço escolar em legais, regulações técnico-construtivos e recomendações higienistas e pedagógicas, em detrimento a outros aspectos de índole antropológica, relacionados à história da escola como lugar de sua real materialidade no tempo imediato de pensamento pedagógico ao pertencimento local. Existem três dimensões que resultaram na invisibilidade ou na percepção do espaço escolar, segundo o autor.

A primeira dimensão é a alusão à distribuição e aos usos dos espaços que a escola ocupa, não indo além da mera informação sobre os edifícios em que se localiza a instituição, acompanhada, no melhor dos casos, de fotografias e plantas. Para Frago (1998), transformações ocorrem "quando a chamada história social da educação entrou em uma análise micropolítica escolar em relação à pessoa-ambiente diante da dimensão espacial, e a atividade educativa cada vez mais passou a se fortalecer na organização espacial'". A psicologia ambiental já tinha maior campo de ação e trouxe estudos relativos ao emprego que o ser humano faz do espaço, organização prática, na vida cotidiana (FRAGO, 1998, p. 12). 
A segunda dimensão conta com razões explicativas para a escassa atenção aos espaços escolares por parte dos historiadores da educação, dificuldade de integrar diversos pontos de vista profissionalmente distantes, tais como o médico-higienista, o arquitetônico, o pedagógico e o político-administrativo, e também como organizar um curso acadêmico em torno de uma linguagem pedagógica que amplie questões transversais no caminho, reúna esforços na investigação dos espaços escolares como inclusão ao ensino-aprendizado e promova leituras de trabalhos que despertem ideias tornando possível a percepção ambiental (FRAGO, 1998, p. 17).

Há, todavia, uma terceira razão,

[...] não menos importante. Como também acontece em outros âmbitos, a investigação em história da educação esteve condicionada pelo ensino dessa disciplina. O que quero dizer é que aqueles temas que não tem lugar em um programa normal de ensino, ou que não são um desenvolvimento daqueles temas que figuram em tal programa, têm escassa possibilidade de ser objeto de uma investigação específica (Ibid., p. 14).

Em narrativas de visita a espaços escolares, Frago e Escolano (1998, p. 21) fazem uma capa arqueológica ao observar, em sua memória, vestígios encontrados em duas reformas escolares. Deram destaque às áreas externas do prédio, identificando experiências nos espaços vividos, que não haviam sido completamente destituídos da história construída. Para os referidos autores, a antropologia do espaço possui dimensões e modelos que podem ser observados por meio de simbolismo seja no físico, seja no lírico (Ibid., p. 38-39).

Froebel (apud FRAGO; ESCOLANO, 1998, p. 38) é um grande representante dessa vocação da antropologia arquitetônica. Dessa forma, deixam relatos em que se podem verificar a aprendizagem das primeiras estruturas espaciais na formação do conhecimento pessoa e ambiente.

O lugar que a escola teve de ocupar na sociedade e na vida das pessoas passa por especial atenção no final do século XIX e início do século XX, com reais necessidades de demandas de transformação na atualidade (FRAGO; ESCOLANO, 1998, p. 30), pois, quanto ao edifício e aos campos escolares, há necessidade de criar uma doutrina de urbanismo escolar.

[...] se a escola precisa de uma grande extensão de terreno é porque não consta apenas da sala de aula, mas porque deve ter um campo anexo. Não apenas um jardim ou um horto, elemento interessantíssimo, seja para ensinar certas coisas, seja para educar a fantasia; nem mesmo o pátio, tanque de ar corrompido e imóvel... O campo escolar é, ao mesmo tempo, tudo isso, mas infinitamente mais do que tudo isso. Por mais que sejam suas exigências, jamais devo renunciar a esse elemento, tão importante, pelo menos, como a própria sala de aula, e cuja necessidade é, ao mesmo tempo, higiênica e pedagógica (GINER, 1933, p. 193-236). 
Uma posição que a Pedagogia deveria tomar é a da revalorização das áreas verdes escolares para que sejam organizadas como espaços que possibilitem o desenvolvimento de práticas que interajam com os conteúdos estudados em sala de aula.

As áreas verdes das escolas, no século XXI, devem ser símbolo de esforço que correspondam a seu entorno, a favor de uma cultura ambiental, não como no passado republicano, em que as escolas deveriam ser elemento de percepção dominante da paisagem urbana.

Devido a esse simbolismo, Frago e Escolano (1998) referem-se ao espaço como algo didático na dimensão educativa.

\begin{abstract}
A percepção é um processo cultural. Por isso, não percebemos espaços, senão lugares, isso é, espaços elaborados, construídos. Espaços com significados e representações de espaços. Representações de espaços que se visualizam ou contemplam, que rememoram ou recordam, mas que sempre levam consigo uma interpretação determinada. Uma interpretação que é resultado não apenas da disposição material de tais espaços, como também de sua dimensão simbólica [...]. Nada é melhor do que falar, nesse caso, no valor didático do simbólico, um aspecto a mais da dimensão educativa do espaço (FRAGO; ESCOLANO, 1998, p. 78).
\end{abstract}

\title{
1.4 A EDUCAÇÃO AMBIENTAL ESCOLAR
}

A Educação Ambiental escolar surge a partir da Lei n. ${ }^{\circ}$ 9.795, de 27 de abril de 1999, regulamentada pelo Decreto n. ${ }^{\circ}$ 4.281, de 25 de junho de 2002, que também institui a Política Nacional de Educação Ambiental - PNEA. Esse decreto afirma que a Educação Ambiental é componente essencial e permanente da educação nacional, devendo estar presente, de forma articulada, em todos os níveis e modalidade bem como inserida no currículo escolar como tema transversal do processo educativo e em conformidade com os Parâmetros Curriculares Nacionais - PCNs, que estabelecem a relevância e a obrigatoriedade da Educação Ambiental (MEC, 2006).

A Educação Ambiental não é um tipo específico de educação, mas constitui um elemento estruturante que demarca um campo político-pedagógico de valores e práticas, mobilizando atores sociais comprometidos com uma ação transformadora e emancipatória capaz de promover a ética e a cidadania ambiental.

A incorporação dessa educação pela via transdisciplinar torna-se cada vez mais necessária diante do atual contexto nacional e mundial em que cresce a preocupação com as mudanças climáticas, a degradação da natureza, a redução da biodiversidade e os riscos socioambientais locais e globais, ou seja, as necessidades evidenciam-se na prática social. A escola é um espaço fértil para esse processo de formação. 
A atuação da Educação Ambiental pode ocorrer em um campo vasto. Na educação escolar, apresentam-se os seguintes objetivos:

a) estimular a reflexão crítica e propositiva na formulação de projetos pedagógicos das instituições de ensino, para que a concepção de Educação Ambiental no currículo supere a mera distribuição do tema pelos componentes curriculares.

b) orientar os docentes da Educação Básica em sistemas educativos; e

c) contribuir para a formação humana do sujeito que vive em determinado meio ambiente, com um contexto social histórico e sociocultural, com suas condições físicas, emocionais, intelectuais, culturais e éticas.

Albert Schweitzer (apud HOSSNE; FILHO, 2013) cunhou os conceitos de Educação Ambiental e Ética Ambiental diante das tantas catástrofes locais e globais.

\begin{abstract}
Uma ética que nos obrigue somente a preocuparmo-nos com os homens e a sociedade não pode ter essa significação. Somente aquela que é universal e nos obriga a cuidar de todos os seres vivos nos põe de verdade em contato com o universo e a vontade nele manifesta não poderia ser somente voltada para os seres humanos e a sociedade, mas deveria ser universal, abarcando todos os seres e obrigando-nos a cuidá-los (Ibid., p. 210).
\end{abstract}

O primeiro conselho para Educação Ambiental surge na Inglaterra e expande-se por vários países europeus (Dinamarca, Finlândia, França, Islândia, Noruega e Suécia) onde iniciam uma educação ambiental pautada no currículo escolar sob o viés da ética ambiental.

No Brasil, com a Rio-92, a Educação Ambiental ganhou contornos de base conceituais sobre a ética ambiental. Entende-se por ética ambiental uma educação comprometida, de forma crítica, com a realidade, que possua objetivos, que promova o fortalecimento da cidadania para a população como um todo e que seja corresponsável na defesa da qualidade de vida em dois níveis: formal (na escola) e não formal (fora da escola) (DIAS, 2004).

Carvalho (2012), quando se refere à ética ambiental, afirma que a Educação Ambiental deve ser, acima de tudo, um ato político, voltado para a transformação social, capaz de transformar valores e atitudes, construindo, assim, novos hábitos e conhecimento bem como defendendo uma ética que sensibiliza e conscientiza a formação da relação integrada da sociedade com a natureza e aspirando ao equilíbrio local e global como forma de melhorar a qualidade de todos os níveis de vida. A PNEA, no artigo $5 .^{\circ}$, incisos II e $\mathrm{V}$, trata especificamente da questão ética.

A Educação Ambiental tem assumido, nos últimos anos, o grande desafio de garantir a construção de uma sociedade sustentável, em que se promovam, na relação com o planeta e seus recursos, valores éticos como cooperação, solidariedade, generosidade, tolerância, dignidade e respeito à diversidade. 
A Educação Ambiental deve ser trabalhada na ética escolar e não por uma exigência do MEC, pela PNEA ou em conformidade com os PCNs, mas porque se entende ser a única forma de aprender e ensinar que os homens não são os únicos habitantes deste Planeta.

Dentre as várias formas possíveis de trabalhar com a Educação Ambiental, uma é afirmá-la por meio da transversalidade, na qual as práticas pedagógicas se efetivam quando as barreiras entre as várias disciplinas e entre os profissionais da educação forem eliminadas, a partir de temas essenciais ligados ao meio ambiente. Para que isso ocorra, os conteúdos devem reunir informações dentro de um contexto nas várias disciplinas para as práticas pedagógicas, criando novos espaços de transferências didáticas além-sala de aula.

[...] escolas são espaços privilegiados para aprender-ensinar porque lá as crianças colhem suas primeiras sensações, impressões, sentimentos do viver. Sendo assim, a dimensão ambiental não poderia estar ausente, ou a serviço da dimensão cultural, ambas deveriam estar absolutamente acopladas (TIRIBA, 2008, p. 2).

Os espaços escolares nas instituições de ensino são lugares que podem abrigar práxis ${ }^{2}$ pedagógicas. Explorar as áreas verdes como outros lugares de ensino-aprendizado inclui coerência teórica e prática, vinculando condições objetivas para efetivar as propostas do plano de aula.

Às vezes, a sala se apresenta como um espaço mental, mais ou menos coerente e charmoso, e a atmosfera parecia então clara, agradável e respirável; outras vezes, ao contrário, havia um acúmulo de pensamentos e de sentimentos, flutuantes e imóveis, um conjunto pesado, não passível de transformação e opaco a todo conhecimento. Mas se eu era o principal responsável por uma atmosfera desse tipo, o auditório também o era. Quando, se respira o ar dos sentimentos e das ideias, as vicissitudes meteorológicas do ambiente traduzem a natureza e o estado mental do conjunto (SALOMON RESENILK apud BLANCHARD-LAVILLE, 2005).

Quanto à educação com vicissitudes ambientais, voltada para os espaços verdes livres da escola numa perspectiva de uso, deve-se entender o complexo do lugar enquanto percebido e vivido por pessoas, respeitando as suas tradições e os seus valores culturais.

O complexo é aquilo que é tecido juntamente, elementos heterogêneos inseparavelmente associados, paradoxo do uno e do múltiplo. Tecido de eventos, ações, interações, retroações, determinação e acasos do mundo fenomenal. A desordem faz parte da ordem. A ciência clássica, ao descartar o incerto, o imponderável, o ambíguo, reteve a ordem, simplificando a realidade ao extremo (FLORIANI, 2000, p.33).

Na elaboração do plano de aula, as áreas verdes livres podem vir a ser vislumbradas como potencializadoras ou colaboradoras de espaços educativos à Educação Ambiental em práticas didáticas de ensino dirigidas por diferentes áreas dos saberes. Quando se abre a pauta

\footnotetext{
${ }^{2} \mathrm{Na}$ pedagogia, práxis é o processo pelo qual uma teoria, lição ou habilidade é executada ou praticada, convertendo-se em parte da experiência vivida.
} 
"didática de ensino" se utilizando do uso da área verde como espaços educativos, estes devem ser entendidos como espaço psíquico de transferência didática (BLANCHARD-LAVILLE, 2005). Essa autora propõe que, ao passar uma enunciação didática ou uma fala do conteúdo a ser apresentado, o professor se preocupa com um discurso que se vincula a esse enunciado, situando temas embreantes e imbricados ao assunto dos conteúdos propostos e, assim, ocorre a transferência didática do professor. "É a ecologia [...], dessa transferência didática que nos interessa [...] desenvolvem os movimentos do pensamento e da aprendizagem dos alunos" (ibid., p. 234).

Abordar as áreas externas escolares é entender que essas podem servir de lugares que aportam práticas pedagógicas e que, antes de tudo, servem para despertar na criança a curiosidade, levando-a, depois, a explorá-las, permitindo-a aprender por meio das descobertas e das apropriações realizadas em seu interior.

A tomada de decisão quanto aos benefícios que as áreas verdes, como promotora de lugares ao ensino aprendizagem, podem ofertar certamente faria os professores avançarem por uma Educação Ambiental que:

a) fomente uma educação que tenha em seu propósito a abordagem em práticas didáticas dirigidas que podem acontecer em áreas verdes livres;

b) mostre os locais cujos usos dos espaços, seus objetos, seus elementos diversificados constituídos, com a vida existente nele, o ar, a luz, o calor, a fauna, a flora, são apoiadores para práticas variadas de áreas dos saberes docentes em suas práxis;

c) credite valores ambientais eco pedagógicos e formativos no sujeito aprendente;

d) promova um currículo escolar que perpassa pelas áreas dos saberes procurando despertar, em todos, a consciência de que o ser humano faz parte do meio; e

e) use a temática meio ambiente de forma transversal, pois a Educação Ambiental pode estabelecer trabalhos coletivos que envolvam a visibilidade, o uso e a função das áreas externas livres verdes. O homem é um sujeito que aprende, nele se dá a alteridade.

Não sendo de responsabilidade única o papel de formar/transformar o sujeito em sujeito ecológico com capacidade de produzir sentido ambiental (SATO; CARVALHO et al., 2005, p. 54), a Educação Ambiental permeia todas as disciplinas, as quais, com seus conteúdos específicos, enriquecem suas práticas e legitimam interpretações da perspectiva ecológica do desenvolvimento humano em áreas verdes livres. 


\begin{abstract}
A Educação Ambiental não sendo uma matéria suplementar que se soma aos programas existentes, exige a interdisciplinaridade, quer dizer, uma cooperação entre as disciplinas tradicionais, indispensável para poder se perceber a complexidade dos problemas do meio ambiente e formular sua solução (SATO; CARVALHO et al., 2005, p. 123).
\end{abstract}

A educação deve ser entendida também pelos seus pares que, ao abordar nos Temas Transversais 'o meio ambiente', tomam decisões de atender à Política Nacional de Educação Ambiental e comprometam-se com ações de corresponsabilização com o Iave, recomendadas pelo MEC. A Secretaria Estadual da Educação de São Paulo legitima essas áreas, pois, na maioria, as 71 escolas da Diretoria de Ensino Norte 2, na capital paulista, possuem áreas verdes que diferem em tamanho e intencionalidade de uso.

A Educação Ambiental escolar, quando inserida no planejamento curricular, levando em consideração as idades, as especificidades das fases, etapas, modalidades e a diversidade sociocultural, age no sentido de procurar formar indivíduos, grupos ou coletivos que se apropriem de valores sociais construídos, de conhecimentos adquiridos, de habilidades desenvolvidas e de atitudes praticadas. Para isso, utiliza-se de uma Educação Ambiental que promove o respeito à conservação, à preservação ou à recuperação do meio ambiente e também à mudança de atitude bem como o repensar das próprias necessidades e valores dos sujeitos.

Nesse sentido, a Educação Ambiental possibilita que se dê uso, função e destino aos espaços livres verdes das escolas, com foco pedagógico, tornando-os adeuados às práticas de ensino-aprendizado; destacando que, de forma livre, com interesse individual ou grupal, podem servir também ao descanso, à recomposição de energia ou ao gasto, à socialização, ao lazer, às práticas culturais, ao idílico e ao aprazível, podendo se tornar importantes pontos de apoio para a construção e transformação da percepção do ambiental que os indivíduos que frequentam a escola têm.

As educações, incluindo a Educação Ambiental, devem conscientizar da importância da formação de hábitos, costumes e valores de uma comunidade para que esses possam ser herdados e transferidos de geração para geração. A educação transforma-se por meio de situações presenciais e experiências vividas pelo indivíduo ao longo de sua vida. A Educação Ambiental é aquela que provoca uma visão transformadora não limitante, restrita ou reducionista (plantando árvores/fazendo horta), mas em dimensão de ecologia humana. 
A ecologia humana ${ }^{3}$ inclui entender o comportamento humano a partir da sua diversidade no espaço, da diversidade de respostas sociais e culturais de diferentes pontos de vista, em perspectiva global, ao enfatizar a contribuição de vários saberes - físico, químico, biológico, demográfico, geográfico, sociológico, econômico, técnico, cultural, espiritual etc., que possibilitam formar a base da ecologia humana para o entendimento acerca da relação pessoa-ambiente (BEGOSSI, 1993).

As áreas verdes livres podem se constituir como espaços educativos sob o aspecto da ecologia humana ao estimular no aprendente um ensino aprendizado envolvendo diferentes professores e campos de saber a partir da realidade comum de um espaço concreto. Em diferentes tamanhos e contextos de uso, na sua maioria, oferecem aportes pedagógico e metodológico, pois fomentam lugares educadores sustentáveis, integrando a proposta curricular ao incentivar a pesquisa de campo e aprimorando a prática discente e docente da cidadania ambiental (BRASIL, 2013, p. 560).

Hoje, essas áreas estão invisíveis, esquecidas, fechadas, gradeadas, muradas e cercadas, mas podem revelar um potencial a ser explorado no contexto escolar pela Educação Ambiental Transdisciplinar.

A educação, como espaço transdisciplinar, revela que as fronteiras entre os campos do conhecimento se entrecruzam, levando a capacidade de dialogar com várias áreas do conhecimento (ARANTES, 2006, p. 7). Esse é um desafio em que o professor, como mediador de produção do saber científico e pedagógico, leva seu conhecimento e experiência para desenvolver um contexto do ensino-aprendizagem numa abordagem de interface com a natureza, superando a visão despolitizada, acrítica, ingênua e naturalista ainda muito presente na prática pedagógica das instituições de ensino (BRASIL, 2013, p. 558). Isso envolve apropriar-se de conhecimento teórico-metodológico que busca qualificar os espaços escolares, as áreas verdes, como espaço de uso.

A Educação Ambiental reafirma-se como componente de uma prática educativa integrada (BRASIL, 2013 p. 558) ao articular-se com projetos pedagógicos, atividades didáticas em espaços não formais educativos, podendo regulamentar, direcionar ou mesmo

\footnotetext{
${ }^{3}$ Encíclica papal do Santo Padre Francisco. A Ecologia Humana. O cuidado da casa comum. Fraqueza das reações. "O problema é que não dispomos ainda da cultura necessária para enfrentar esta crise e há necessidade de construir lideranças que tracem caminhos, procurando dar resposta às necessidades das gerações actuais, todos incluídos, sem prejudicar as gerações futuras. Torna-se indispensável criar um sistema normativo que inclua limites invioláveis e assegure a proteção dos ecossistemas, antes que as novas formas de poder derivadas do paradigma tecno-econômico acabem por arrasá-los não só com a política, mas também com a liberdade e a justiça." (CNBB, 2015).
} 
creditar maiores propostas ao organizar formas de trabalho acerca dos procedimentos de trocas didáticas em áreas externas.

A educação não formal é toda atividade organizada, sistemática e educativa realizada fora do marco do sistema oficial para facilitar determinados tipos de aprendizagem em grupos específicos da população, tanto adulto como infantil (COOBS apud CASTELLAR, 2012).

As áreas verdes livres da escola como espaços que possibilitam um processo informal de educação mostram que nelas podem ocorrer diferentes atividades no sentido de articular, diferentes conteúdos escolares a partir de diferentes linguagens como cartografia, literatura, matemática, ciências, botânica, física e outras, a fim de dar significados aos conteúdos de aprendizagem numa perspectiva de ampliação, nos sujeitos, da compreensão e da própria percepção da importância e do sentido destes conteúdos na sua vida.

As Diretrizes Nacionais para a Educação Ambiental, quanto às áreas externas livres escolares, informam que:

\begin{abstract}
Cabe considerar, por oportuno, os chamados "espaços educadores sustentáveis", assumidos como um princípio da educação (Decreto $\mathrm{n}^{\circ} 7.083$, de 27 de janeiro de 2010 - artigo $2^{\circ}$, inciso V). A proposta de criação desses espaços educadores está presente também no Plano Nacional sobre Mudança do Clima (PNMC, parte IV.4, item 12, 2008). Espaço educador sustentável é aquele que tem a intencionalidade de educar para a sustentabilidade, tornando-se referência para o seu território, a partir das ações coerentes entre o currículo, a gestão e as edificações. Nesse sentido, os sistemas de ensino da Educação Básica, juntamente com as instituições de Educação Superior, devem incentivar a criação desses espaços, que enfoquem a sustentabilidade ambiental e a formação integral dos sujeitos, como também fontes de financiamento para que os estabelecimentos de ensino se tornem sustentáveis nas edificações, na gestão e na organização curricular.
\end{abstract}

Ao organizar no currículo escolar o Projeto Pedagógico e/ou as atividades didáticas cotidianas quanto ao uso dos espaços externos escolares para aprendizagem significativa, entende-se que novas informações se estruturam no indivíduo, pois, de maneira substantiva e relevante, potencializam os conhecimentos teóricos adquiridos indoor - sala de aula -, relacionando-os de forma complementar em face das práticas didáticas dirigidas. A aprendizagem significativa caracteriza-se pela interação cognitiva entre o novo conhecimento e o conhecimento prévio (MOREIRA, 2010, p. 4). Ao se relacionar com quaisquer espaços que não sejam a sala de aula (um espaço formal), fundamentam-se concepções do campo pedagógico de externalidade perceptiva educativa com objetivos de transmissão de saberes viabilizando outras maneiras ao processo de ensino (CASTELLAR, 2012, p.121).

Nos espaços escolares, os projetos destacam que não apenas os alunos ganham, mas os professores também, pois aqueles agregam elementos que ampliam repertório estimulado no campo do conhecimento, um olhar transdisciplinar. 
Em atividades extras salas, orientadas e dirigidas, espaços escolares específicos e exclusivos, encontram-se exemplos em que os professores criam formas próprias ao ensino-aprendizagem com a utilização mais livres dos ambientes escolares.

Para uma prática em área externa verde escolar, requer a exigência de foco específico na relação pessoa-ambiente.

\subsection{A RELAÇÃO PESSOA-AMBIENTE}

Estudos na perspectiva pessoa-ambiente são realizados em várias abordagens.

Em experimento planejado na perspectiva da relação quanto à "participação multiambiente", utilizaram-se dos espaços para estudos comportamentais, creches, jardins de infância e pré-escola (CAMPOS-DE-CARVALHO, 2002; FERNANDES, 2006).

Na saúde, estudos sobre pessoa-ambiente têm sido mais intensificados e usados em relação a pessoas com necessidades especiais e em reabilitação (DE CARLO; LUZO, 2004; HOLANDA, 2003).

Já no caso da Educação Ambiental, esses estudos abordam a interpretação da realidade, com relação à percepção do lugar (RIO et al. 1996).

Outrossim, essa pesquisa que desenvolvi soma-se ao espectro acima, pois, amplia os estudos da relação pessoa-ambiente, refletindo sobre a importância da percepção ambiental das áreas verdes escolares pelos professores para que estas possam ser aproveitadas ao potencial papel da Educação Ambiental.

Os estudos sobre o ambiente atestam que a transição mais intensa no desenvolvimento humano ocorre na passagem do lar para a escola. Isso revela que, na saída de um ambiente para outro, acontece uma “transição ecológica” (BRONFENBRENNER, 1996, p.161), ou seja, quando uma pessoa em desenvolvimento tem mais de um vínculo primário em um mesossistema, ela propõe-se a realizar atividades de compartilhamento e cooperação. Essa transição ecológica (lar/escola) ocorre interiormente no indíviduo, em que a diversidade de ambientes pode desencadear um processo formativo. Isso depende do envolvimento das áreas dos saberes numa educação ambiental.

Mesossistema compreende os elos e processos que ocorrem em dois ou mais contextos que contêm a pessoa em desenvolvimento, pois ela se engaja em atividades, papéis e relações interpessoais, conforme ambientes diferentes, por exemplo, a escola, a creche etc. (CAMPOSDE-CARVALHO, 2008, p. 18). 
[...] é preciso que o homem, sobretudo na infância, acostume-se a conviver com a natureza, considerando-a em seus fenômenos [...] nada há que una tanto um professor com um discípulo como a contemplação dos objetos naturais e o estudo comum da natureza [...] não deveriam se esquecer disso [...] nem os professores na escola. Conviria que esses últimos levassem para o campo, pelo menos uma vez por semana, um grupo de alunos (FROEBEL, 2001, p. 103).

Considerando que o desenvolvimento do sujeito abarca os múltiplos ambientes e que as inter-relações ocorrem de forma recíproca, a díade de ligação pessoa-ambiente que envolve sempre o novo membro na comunidade escolar é o professor. Uma díade é sempre formada quando as pessoas prestam atenção às atividades umas das outras ou delas participam.

O potencial desenvolvimento dos ambientes num mesossistema é aumentado se as exigências de papel nos ambientes são compatíveis e se os papeis, atividades e díades em que a pessoa se envolve encorajam o desenvolvimento da confiança mutua, de uma orientação positiva, de um consenso de objetivos entre os ambientes e de um equilíbrio de poder que evolui em favor da pessoa desenvolvente [...]. Em qualquer ambiente, uma díade que envolve uma pessoa de ligação como membro é chamada de díade de ligação (BRONFENBRENNER, 1996, pp. 162-163).

Estudos centrados na pessoa-ambiente, a partir dos vestígios ambientais deixados pelos usuários em um determinado local, revelam uma "arqueologia do comportamento" (SOMMER; SOMMER, 1997 apud ELALI et al., 2008, p. 79), pois possibilitam constructos sobre a percepção ambiental no que se refere à compreensão de ocupação, de uso ou de aproveitamento a que os indivíduos aderem como atributo para um determinado ambiente; um deles, o de exercerem suas atividades diárias.

Ao focar as relações pessoa-ambiente nas escolas, o território mais frequente são as salas de aula. Espaços fechados com conceitos e parâmetros em ambiente de ensino que já foram muito explorados pela arquitetura (KOWALTOWSKI, 2011) em diversas categorias, como conforto, acústica, luminosidade, ergometria das carteiras e cadeiras, acessibilidade, espaços flexíveis, elementos de sustentabilidade, cor, termodinâmica, conexões entre espaços etc., desconsideraram a influência das pessoas em seus ambientes.

Trabalhos multidirecionais que se propõem a estudar a perspectiva dos sistemas de ambientes, que interferem no desenvolvimento do sujeito aprendente, declaram que as áreas livres verdes de uma escola podem ser lugares de melhor interpretação de sensações do ser humano na ótica da relação pessoa-ambiente; o frio, o calor, a luz, a cor, o som, o cheiro, o tato e a visão, em dose maior sensorial, ampliam a captação de todos esses elementos. Os traços comuns na percepção do sujeito advêm dos sentidos em contato com as sensações da pessoa para com o ambiente: "Se podemos ouvir e cheirar algo, podemos muitas vezes também vê-lo. Quais os órgãos sensoriais e as experiências que permitem aos seres humanos 
ter sentimentos intensos pelo espaço e pelas qualidades espaciais? Respostas: cinestesia, visão e tato" (Ibid., p. 21).

Quanto às sensações e às interpretações da perspectiva ecológica do desenvolvimento humano para compreender as inter-relações da pessoa com as áreas verdes escolares do entorno predial, a educação encontra na psicologia ambiental aportes a serem explorados no contexto pedagógico, o que pode subsidiar ou fortalecer as ações de Educação Ambiental.

O potencial "desenvolvimental" humano ocorre quando há uma interação entre a pessoa e o ambiente que, além de produzir mudança no sujeito, pode dar continuidade de ação, capacidade de descoberta, manter ou alterar propriedades do ambiente que, por sua vez, também exerce influência de alteridade na pessoa. Para Bronfenbrenner (1996, p. 177), à medida que as creches, as pré-escolas e as escolas ocupam os subúrbios/periferia da cidade, tornam-se um composto físico e socialmente isolado da vida da comunidade a que se propõem atender, onde as "crianças são segregadas em salas que geralmente trocam todos os anos", revelando que "as salas de aulas têm pouca ou nenhuma identidade social própria".

Na perspectiva da pessoa-ambiente - crianças e adolescentes -, estudos experimentais de campo esclarecem que potenciais índices de desenvolvimento ocorrem influenciados pelas transições e interconexões ecológicas entre os ambientes. O índice de desenvolvimento do sujeito ocorre numa diversidade de ambientes que vai começando a experienciar, de forma cada vez mais precoce, ao sair de casa e indo para berçários, creches, pré-escola, escola e outros ambientes com equipamento social.

Pedagogos e educadores, ao estudarem a fase pré-escolar, construíram um arcabouço teórico para o desenvolvimento da criança. Para eles, brincadeiras e ludicidade ajudam e potencializam a construção cognitiva ambiental a partir de atividades em áreas externas.

A cognição ambiental é um conceito genérico e que se refere ao repertório de conhecimento do sujeito com o seu entorno físico e ou social (ARAGONÉS, 2002). Assim, a escola-parque e os parques infantis buscavam integração entre escola e natureza. De certa maneira, já se abriam possibilidades e preocupações para uma educação com vivência ambiental que se estenda em conjunto com aquelas outras que ocorrem nos espaços fechados das salas.

Elali (2003), investigando sobre a relação ambiente-escola na educação infantil, aponta a necessidade de as crianças mais novas terem contato com ambientes naturais. Com o avanço da idade, essa necessidade volta-se para a aceitação social, o que leva os jovens a se interessarem gradativamente pelas atividades em grupo em áreas relativamente fechadas e pelo uso de novas tecnologias como fonte de experiências lúdicas. 
Demandas educacionais que exigem potenciais áreas livres pedagógicas a serem criadas nas escolas são frutos de estudos em experiência espacial humana sobre o desenvolvimento humano, centrados em específico nas relações humano-ambiental. Somente a partir da década 1970, a psicologia ecológica, ou a ecologia, revelava que carências múltiplas podem ser oriundas de privações socioafetivas de contato com o espaço físico na formação complementar do desenvolvimento do sujeito em ambiente não cercado por elementos naturais. 


\section{OBJETIVOS}

Quando eu nasci, um anjo torto desse que vivem na sombra disse: Vai, Carlos! ser guache na vida (Carlos Drummond de Andrade. Poema de sete faces)

\subsection{OBJETIVO GERAL}

Estudar a percepção dos professores de uma escola pública na capital paulista em relação às áreas verdes livres do entorno predial escolar e a possibilidades de uso dessas como espaços pedagógicos.

\subsection{OBJETIVOS ESPECÍFICOS}

- Mapeamento do uso da área verde livre existente na escola.

- Identificar a percepção dos professores sobre as áreas verdes livres existentes na escola onde atuam. 


\section{O MÉTODO}

\subsection{CONTEXTO DA PESQUISA}

[...] todo saber é fragmentário e de que em cada grau de conhecimento alcançado permanece um resíduo não resolvido. (FREUD, apud BLANCHARD-LAVILLE, 2005 p. 163)

O trabalho foi desenvolvido na Escola Estadual Professora Philomena Baylão, situada à Av. Cel. Sezefredo Fagundes, n. ${ }^{\circ}$ 14.666, CEP 02306-005, Jardim Cachoeira, capital paulista. Mantida pelo poder público estadual, administrada pela Secretaria de Estado da Educação e jurisdicionada à Diretoria de Ensino Região Norte 2 da cidade de São Paulo; a escola foi criada pelo Decreto n. ${ }^{\circ}$ 40.146, publicado no Diário Oficial do Estado, de 27 de maio de 1962, e autorizada pela Resolução SE 24/76, publicada no Diário Oficial do Estado, de 29 de janeiro de 1976, com os cursos Ensino Fundamental I e II; Resolução Secretaria Estadual da Educação 95, publicada no Diário Oficial do Estado, em 13 de junho de 2002, referente ao Ensino Médio. São 42 docentes atendendo 1.101 discentes. Essa escola possui:

a) alto Iave, 23,82 $\mathrm{m}^{2}$ por aluno; área construída, 2.030,00 $\mathrm{m}^{2}$; e área total, 25.562,49 $\mathrm{m}^{2}$. A maior área externa livre verde de todas as 71 escolas que compõem a Diretoria Norte 2 de Ensino da capital paulista;

b) área verde protegida pelo Núcleo de Obras e Manutenção Escolar - NOM. Órgão vinculado à Secretaria Estadual da Educação do Estado de são Paulo;

c) nas proximidades, um diversificado conjunto arquitetônico de instalações que podem servir como aportes ao encontro de uma educação cidadã no espaço intramuros escolar; e

d) dependência do maior parque metropolitano do mundo ${ }^{4}$ que abastece a cidade em $30 \%$ da capacidade do consumo de água devido a seu rico conjunto de nascentes da bacia do Rio Tietê na metrópole.

A Escola Estadual Professora Philomena Baylão difere seu potencial de estudo em detrimento a outras unidades de ensino, devido ao aporte generoso do Iave de entorno predial e por ter uma área contínua não fragmentada, aberta com a presença do prédio escolar

\footnotetext{
${ }^{4}$ Parque Estadual Serra da Cantareira.
} 
fortificado na centralidade do terreno, conforme imagem via satélite. Esta imagem foi a base de observação para ordenar a pesquisa sobre a percepção ambiental do espaço externo.

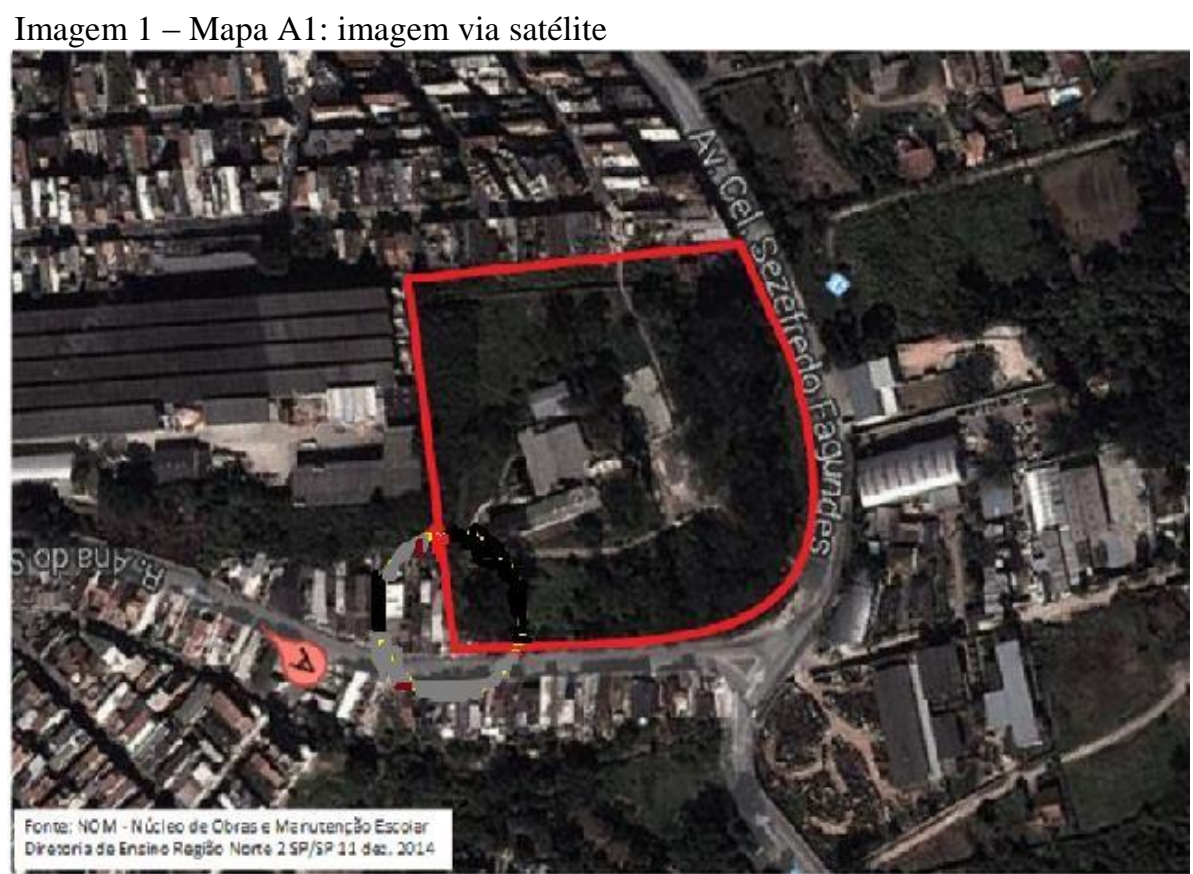

Fonte: NOM - Núcleo de Obras e Manutenção Escolar Diretoria de Ensino Região Norte 2 SP/SP. Nov. 2014.

Percebe-se a centralidade do edificio escolar cercado por uma imensa área verde marcada por rota, caminho, estrada, trilha e uma parte erodida que é a praça central. No entorno do território escolar, há uma intensa forma desordenada de ocupação, isso obriga a comunidade a passar por dentro da escola no ir e vir das necessidades diárias em uma metrópole como mostra a fotografia abaixo.

Imagem 2 - Portão de entrada da EE Professora Philomena Baylão

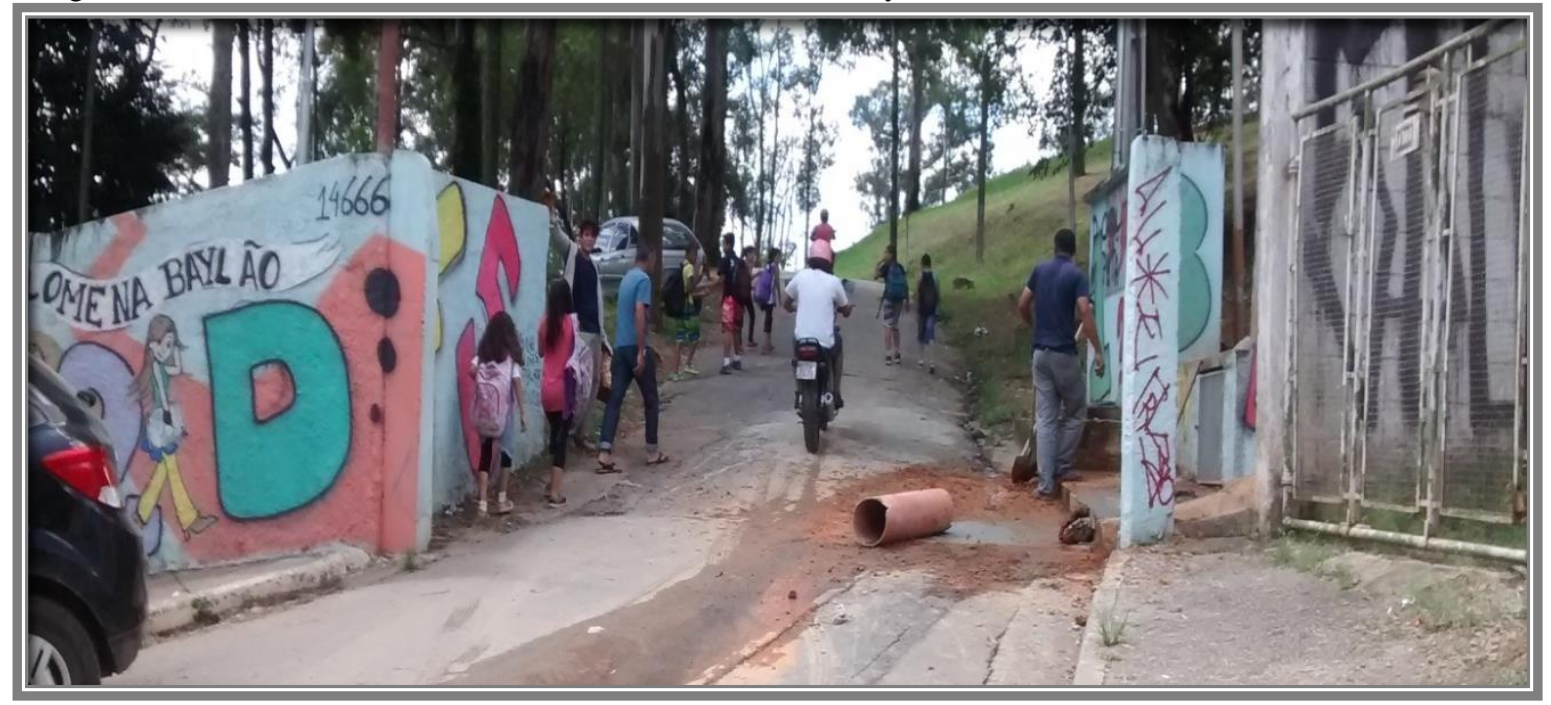

Fonte: fotografia de Foto: João Fernando Pereira Filho, 9 agosto de 2015, às 10h25m 


\subsection{SUJEITOS}

Esta pesquisa foi realizada com seis docentes atuantes em sala de aula, sendo três professores do Ensino Fundamental I e três do Ensino Fundamental II, igualmente distribuídos nos períodos matutino e vespertino e nas áreas de conhecimento: Código e Linguagem; Ciências Hmanas e Ciências da Natureza.

Os sujeitos foram escolhidos pela disposição voluntária de participar da pesquisa quando esta foi apresentada à comunidade e por pertencerem às diferentes áreas do conhecimento.

\subsection{ESTRATÉGIAS}

A pesquisa foi realizada na perspectiva da relação pessoa-ambiente. Esse campo teórico busca, na investigação do ponto de vista dos sujeitos, a intervenção ambiental na compreensão das interrelações com o entorno natural. "Sem a integração da percepção daquele que utiliza o espaço, as intervenções ambientais estarão fadadas ao fracasso." (CAVALCANTE; MACIEL, 2008, p. 149).

A investigação segue um quadro metodológico que mescla estratégias de mapeamento ambiental e entrevistas semi-estruturadas na construção de um mosaico de dados que possibilitem uma compreensão da percepção ambiental dos professores e seus desdobramentos no uso de áreas livres como espaços pedagógicos.

\subsubsection{Observação}

Nesse cenário, a observação responde por conhecer os aspectos efetivamente manifestos do comportamento humano nos ambientes.

A observação, como instrumento inicial de coleta de dados, sistematizou a realidade em registros, os quais deram informações de comportamento centrado no ambiente a partir da maneira como as pessoas transitam nas áreas estudadas. Isso objetiva a compreensão da setorização da área feita pelos professores, sendo constitutivo do método da pesquisa.

O mapeamento comportamental obtém relevância a partir da separação ou fragmentação do espaço em seções específicas, dando facilidade de visualizar provaveis unidades de comportamento em função do objetivo da pesquisa em tempo, tipo, período de utilização do espaço no momento real da coleta de dados. 
Tendo a Escola Estadual Professora Philomena Baylão um alto Iave escolar por $\mathrm{m}^{2} /$ aluno e podendo ser considerada uma chácara, são nos caminhos e passeios internos que o sujeito se identifica, nos limites dos setores, linha de trânsito e nos nós que se encontram. Esses são os marcos que vislumbram o motivo de observação, que utilizam dos vestígios ambientais de comportamento deixados e, ao relacioná-los ao longo do curso da área, caracterizam o uso e a ocupação de um local (LINCH, 1954, p. 58). São nas passagens que as pessoas veem e são vistas, criam imagens e, à medida que nelas se deslocam, outros elementos cognitivos se organizam.

Os dados coletados por observação quanto ao comportamento na área verde escolar foram mapeados a partir de uma rota de observação do pesquisador (Imagem 3, p. 45). Essa rota possibilitou a criação de três mapas: (a) centrado no ambiente e no lugar (Imagem 4, p. 46); (b) de divisão em setores, A, B, C, D, E, F e G, definidos consensualmente pelos sujeitos da pesquisa (Imgem 5, p. 47); (c) de percepção dos professores (Imagem 6, p. 47); e de dois gráficos centrados na pessoa (Gráficos 1 e 2, p. 49) nos períodos de estudo: matutino e vespertino.

O diário de campo também foi valioso recurso no registro da pesquisa, um instrumental simples que "valoriza os insights individuais, oferecendo grande riqueza informacional sobre o uso do ambiente pelos seus participantes do estudo, pois podem ocorrer dificuldades de acesso por razões das mais variadas" (PINHEIRO et al, 2008, p. 281-82).

Dois critérios básicos foram importantes na observação:

a) respeitar, na divisão topológica do espaço, a relevância comportamental em unidades prováveis de comportamento por setores que foram definidos consensualmete pelos sujeitos da pesquisa (ELALI; FERNANDES; PINHEIRO, 2008, p. 87).

b) visualizar ocupação local por setor a partir de elementos ou vestígios com fortes referências visuais, materiais, marcas, simbologias, apegos, sentimentos, aconchegos como integradoras de uso. Arqueologia espacial do lugar (TUAN, 2013; FRAGO; ESCOLANO, 1998).

\subsubsection{Entrevistas}

As entrevistas foram realizadas durante uma caminhada do autor, junto com os professores, pelas áreas da escola, seguiram o padrão walking around, desenvolvido por Gunter (2008). Foram sete perguntas, divididas em duas partes e adaptadas à literatura (RIO, 1996), buscando conhecer alguns níveis da percepção ambiental dos respondentes. 
No primeiro nível, investigou-se a conduta. Nesse momento, buscou-se compreender a capacidade de perceber, conhecer, representar, apresentar, pensar sobre os lugares, no caso, as áreas verdes livres do entorno predial escolar.

O segundo nível foi composto por questões que buscaram conhecer as ideias dos professores sobre o entorno da escola, avaliando a percepção de identificação e representação da área externa. Esse nível caracteriza-se pela adoção das categorias perceptivas criadas.

Os níveis de processo perceptivo trazem informação da preferência pessoa-ambiente, pois criam situações em que os sujeitos expressam oposições qualitativas ao lugar (RIO, 1996, p. 20) e representam um método de pesquisa da organização espacial que oportuniza os sujeitos estruturarem valores crescentes e decrescentes com relação ao local estudado. Isso proporcionou, em sistemas de escala, um diferencial semântico, expressar valores de posições qualitativas de percepção. Partindo do positivo de aconchego (+3), passando pelo (0) neutro ou indiferente e indo para o negativo, desagradável (-3). Essas graduações em construção investigatórias foram inspiradas na escala de Likert (RIO, 1996, p. 16) e na organização de valores crescentes e decrescentes de lugar (TUAN, 2013).

\subsection{INSTRUMENTOS}

Os instrumentos a seguir, possibilitam formalizar um paste-up em coleta de dados, na construção gráfica das formas de uso, representação, apropriação e percepção da área verde escolar (CAMPOS DE-CARVALHO, 2008; DOWNS, 1977; ELALI, 2003; GIBSON, 1974; GUNTHER, 2008; LINCH, 1954; RIO, 1996; TUAN, 2013). São eles:

a) Roteiro de Entrevista, conversa com propósito (Apêndice A, p. 70).

b) Ficha de Identificação dos sujeitos (Apêndice B, p. 71).

Recurso: visual em imagens, audiovisual, folders e materiais de uso pedagógico sobre espaços escolares (livros, revistas, mapas, jornais etc.), criando um ambiente em método de experimento planejado. Essa proposta é oriunda de estratégias ecológicas utilizadas em estudos para analisar a relação entre o arranjo espacial e o aspecto físico do ambiente, relativos à maneira como dispõem os objetos e a ocupação do espaço pelo sujeito, verificando a contribuição quanto à oportunidade de interação e percepção. Os materiais que foram utilizados pelos sujeitos são: 18 cópias da carta cartográfica escolar em curva de nível no tamanho A4, 1 telefone celular com câmera e vídeo, 1 caixa de lápis de cor, 1 gravador, 6 cópias da ficha de identificação e uma prancheta. 


\subsection{PROCEDIMENTOS}

Os procedimentos se deram em três fases.

a) Primeira fase, mês de agosto de 2015 .

- Apresentação da pesquisa aos sujeitos, 18 de setembro 2015.

- Memorando de autorização de pesquisa / Diretoria Regional de Ensino (Anexo 1, p. 72).

- Termo de Consentimento Livre e Esclarecido (Anexo 2, p. 73).

- Termo de Cooperação (Anexo 3, p. 74).

- Disponibilização da Pesquisa para consulta e sugestões na mídia escolar (blog, Facebook e site).

- Abordagem direta de controle com os sujeitos da pesquisa para identificar uma amostragem em seleção intencional de seis participantes voluntários (CRESWELL, 2010, p. 180).

b) Segunda fase, mês de setembro de 2015 .

- Observação com registro de mapeamento por setor, centrado no ambiente (Imagem 4, p. 46) e no comportamento dos sujeitos (Gráficos 1 e 2, p. 49).

c) Terceira fase, mês de outubro de 2015 .

- Entrevista, em conversa, com propósito (Apêndice A, p. 70).

\subsubsection{Coleta de dados}

A coleta de dados foi realizada no total de onze horas, somando os dois períodos (matutino e vespertino), em diferentes dias e horários; teve como observação o ambiente a partir de uma rota (Imagem 3, p. 45) criada pelo pesquisador para explorar a área verde escolar na investigação de vestígios ou resíduos comportamental.

Essa rota foi construída a partir dos marcos existentes no mapa mental de percepção dos professores (Imagem 6, p. 47); isso possibilitou identificar, quantificar e informar os usuários e o comportamento manifestado coletado em:

a) mapeamento centrado no ambiente a partir do registro de vestígio material de comportamento existentes no local, isto é, resíduos ou marcas de uso (Imagem 4, p. 46);

b) construção de dois gráficos (1 e 2, p. 48) - manhã e tarde - centrado na pessoa, em que, por gênero, se registra a forma como ocupam e circulam pelo ambiente; e 
c) formalizar um resumo dos vestígios de ocupação, Ficha de Informações (Tabela 1, p. 46), representando todos períodos.

A coleta de dados - mapeamentos, gráficos e tabelas -, possibilitou classificar, quantificar e comparar resultados, ou mesmo, verificação de semelhanças e discrepância. Isso foi o substrato para o constructo sobre a percepção ambiental e orientou a criação de três categorias: Setor de Visitação, Setor de Prática Didática e Setor de Desejabilidade de Uso, no que se refere à compreensão, ocupação, uso ou aproveitamento que os indivíduos aderem como atributo para um determinado local/setor.

Essas categorias por setores, em valores perceptíveis de paisagem e lugar em interação pessoa-ambiente, partem do positivo (aconchego/agradabilidade) indo ao negativo (desagradável/insegurança). 


\section{RESULTADOS}

A análise dos resultados foi de caráter qualitativo dos dados obtidos nos paste-up, os quais abordam informações coletadas em processo perceptivo; as professoras foram iniciadas no contato com o ambiente pelo estímulo, seguindo pela identificação/reconhecimento e indo até às experiências do sujeito com práticas didáticas em área verde escolar.

Os resultados partem dos paste-up sobrepostos: nos mapeamentos e na classificação geral de paisagem e lugar e das categorias apresentadas na busca de padrões de percepção dos sujeitos. Esse cruzamento fez a compreensão da ocupação, dos usos e dos desejos por setor.

\subsection{PERFIL DOS PARTICIPANTES}

Quanto à participação voluntária de sujeitos que se pré-dispuseram, todos eram do sexo feminino. Foi intrigante esse cenário no desenho de amostragem voluntária com predominância feminina.

[...] reforçando os padrões culturais da sociedade, afeta fortemente a percepção, a atitude e o valor que seus membros atribuem ao meio ambiente. [...]. A cultura pode influenciar a percepção de tal modo que as pessoas verão as coisas [...]. Quanto os papeis de cada sexo são definidos, homens e mulheres, adotam valores diferentes e percebem aspectos diferentes do meio ambiente (TUAN, 2012, p. 338).

[...] das relações de envolvimento com o entorno, tem uma interface significativa com a dimensão temporal, tanto com o tempo de permanência das atividades sociais atuais (época e duração do evento) quanto com o tempo em termos de ciclo de vida, infância, adolescência, juventude, adultez, terceira idade (HIGUCHI, KUHNEN; BOMFIM, 2011, p. 107).

$\mathrm{Na}$ amostragem, como forma de salvaguardar a identidade, foram concionados informativos por codnomes, Apêndice B, p. 71.

a) Matutuino, Ensino Fundamental II, 6. ${ }^{\circ}$ a $9 .^{\circ}$ ano.

Alfa: 50 anos, bacharel em geografia, 5 anos de docência na unidade escolar, vai sempre de ônibus e tem, no planejamento anual, atividades com os alunos usando a área verde.

Beta: 56 anos, bacharel em Arte, 6 anos de docência na unidade escolar, vai sempre de ônibus e tem, no planejamento anual, atividades com os alunos usando a área verde.

Gama: 41 anos, graduação em matemática, 4 anos de docência na unidade escolar, costuma ir a pé ou de carro, não tem, no seu planejamento anual, atividades com os alunos usando a área verde.

b) Vespertino Ensino Fundamental I $1 .^{\circ}$ ao $5 .^{\circ}$ Ano. 
Delta: 50 anos, área do conhecimento Ciências da Natureza e matemática, graduada, 3 anos de docência na unidade escolar, vai sempre de carro e tem, no planejamento anual, atividades com os alunos usando a área verde.

Ômega: 34 anos, área do conhecimento Ciências Humanas, graduada, 6 anos de docência na unidade escolar, vai de ônibus ou de carro e tem, no planejamento anual, atividades com o alunos usando a área verde.

Pi: 58 anos, área do conhecimento Código e Linguagem, bacharel, 2 anos de docência na unidade escolar, vai sempre de carro e tem, no planejamento anual, atividades com os alunos usando a área verde.

Em geral, o período matutino apresentou maior semelhança. As professoras regularmente atravessam a área verde escolar a pé, têm maior tempo de docência na unidade escolar e regularidade em faixa etária. Discrepância: uma professora em todo o espectro não trabalha com os alunos usando a área verde.

\subsection{RETRATO DO AMBIENTE A PARTIR DA OBSERVAÇÃO DOS VESTÍGIOS, OCUPAÇÃO E USO - ESCOLA ESTADUAL PROFESSORA PHILOMENA BAYLÃO}

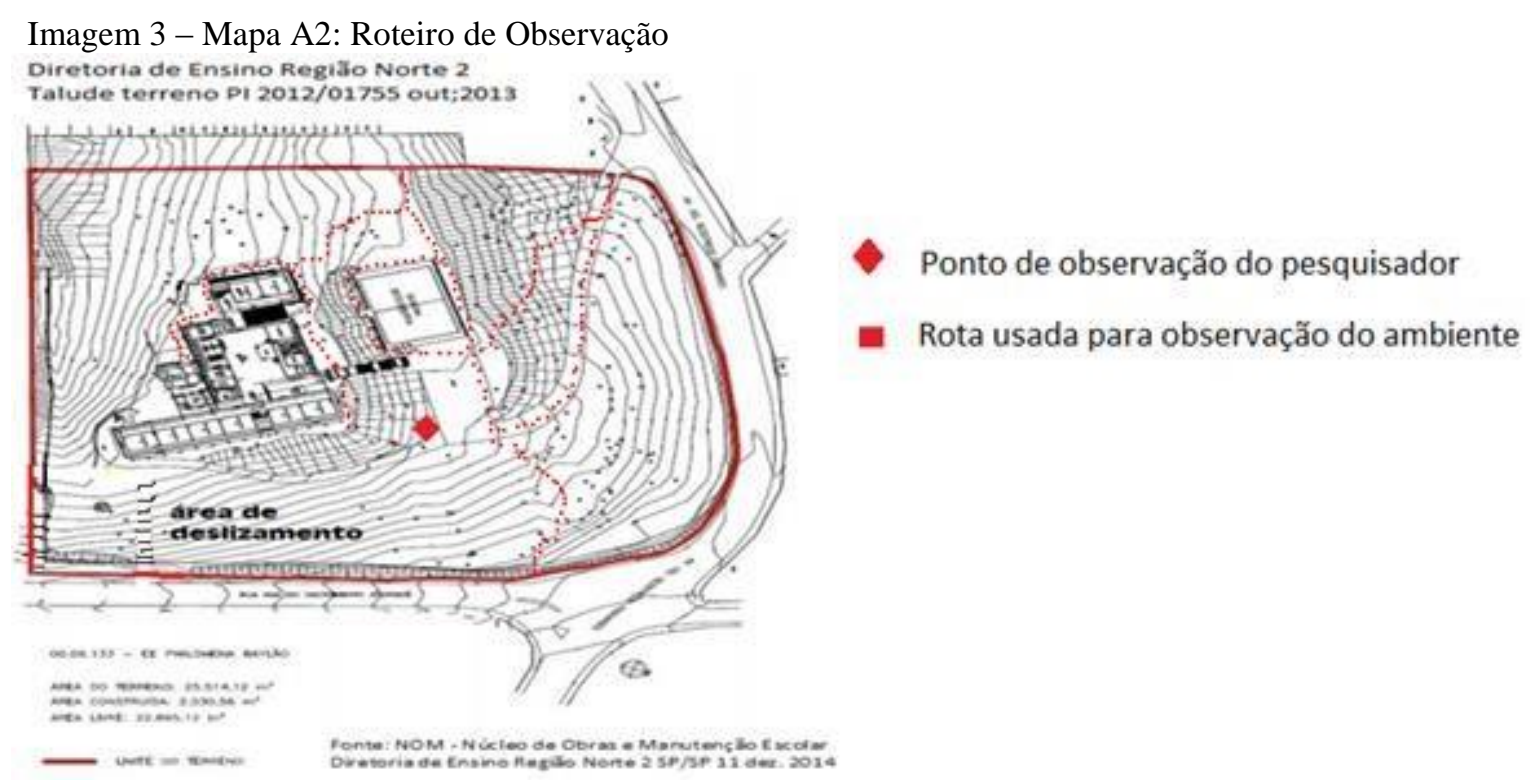

Fonte: NOM - Núcleo de Obras e Manutenção Escolar Diretoria de Ensino Região Norte 2 SP/SP. Nov. 2014.

Essa rota foi construída a partir do aproveitamento dos vestígios de comportamento já existente na área verde. Sinais de ravinamento da passagem humana, queima de lixo, marcas de roteiros que registram as forma de uso. O ponto de observação faz uso da centralidade 
espacial para investigar a ocupação por setores. Nesse local, a visão é de $180^{\circ}$ o que possibilita uma investigação sem grandes esforços para a coleta de dados. Essa rota resultou na elaboraração do mapeamento centrado no ambiente como vestígio de comportamento.

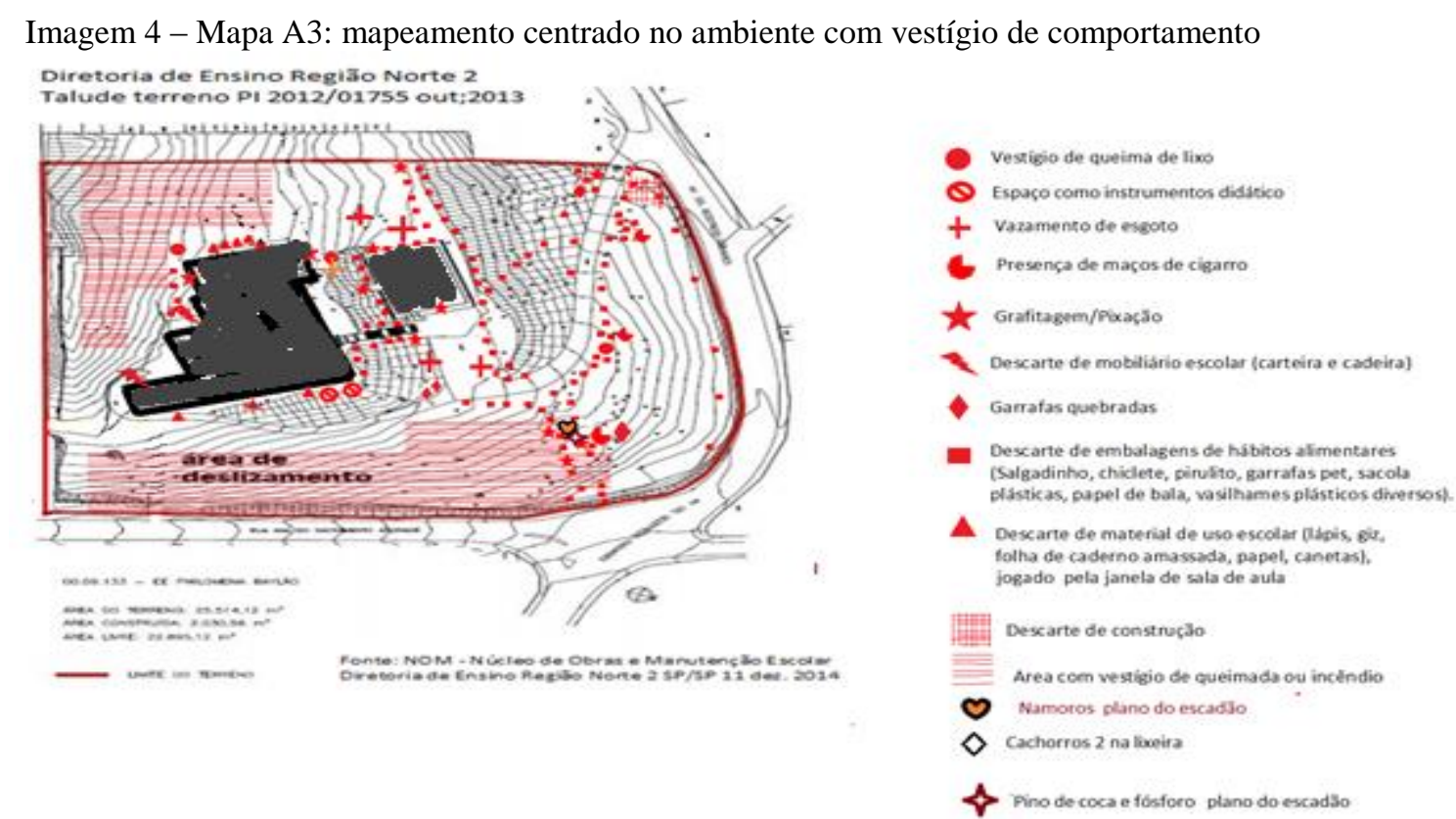

Fonte: NOM - Núcleo de Obras e Manutenção Escolar Diretoria de Ensino Região Norte 2 SP/SP. Nov. 2014.

O mapa acima retrata a área verde de acordo com os vestígios encontrados pelo pesquisador no período de observação. Esse mapeamento tornou possível fazer o resumo, na Ficha de Informação, por setores, com áreas de fuga, perigo, incêndio, lixo, descarte de material mobiliário e etc.

Tabela 1 - Ficha de informação

Tabela 1

Ficha de Informação

\begin{tabular}{|c|c|c|c|c|c|c|c|c|}
\hline \multirow{2}{*}{ AREAS } & \multicolumn{7}{|c|}{ SETORES } & \multirow{2}{*}{ TOTAL } \\
\hline & A & B & C & D & E & $\mathbf{F}$ & G & \\
\hline & & & $\mathbf{X}$ & & $\mathbf{X}$ & & $\mathbf{X}$ & 3 \\
\hline Perien & & & $\mathbf{X}$ & & $\mathbf{X}$ & $\mathbf{X}$ & $\mathbf{x}$ & 4 \\
\hline $\begin{array}{l}\text { Descarte } \\
\text { mobiliário escolar }\end{array}$ & & & & & & $\mathbf{x}$ & & 1 \\
\hline Fogo & & & & $\mathbf{X}$ & $\mathbf{X}$ & $\mathbf{X}$ & $\mathbf{X}$ & 4 \\
\hline Lixo & $\mathbf{X}$ & $\mathbf{X}$ & $\mathbf{X}$ & $\mathbf{X}$ & $\mathbf{x}$ & & $\mathbf{X}$ & 6 \\
\hline TOTAL & 1 & 1 & 3 & 2 & 4 & 3 & 4 & 22 \\
\hline
\end{tabular}

Fonte: observação set/out 2015. 


\subsection{A PERCEPÇÃO DOS DOCENTES A PARTIR DAS ENTREVISTAS}

\subsection{A organização do ambiente em setores e as percepções docentes}

Para construir a imagem da percepção docente, foi entregue duas cartas cartográficas. A primeira para dividir a área verde em setores. Isso organizou a setorização do além-sala de aula para relacioná-lo ao aporte pedagógico na percepção do ambiente Essa atividade solicitada permite interpretar, no tratamento da área livre verde, e avaliar sentimentos, desejos e outros atributos constitutivos da percepção.

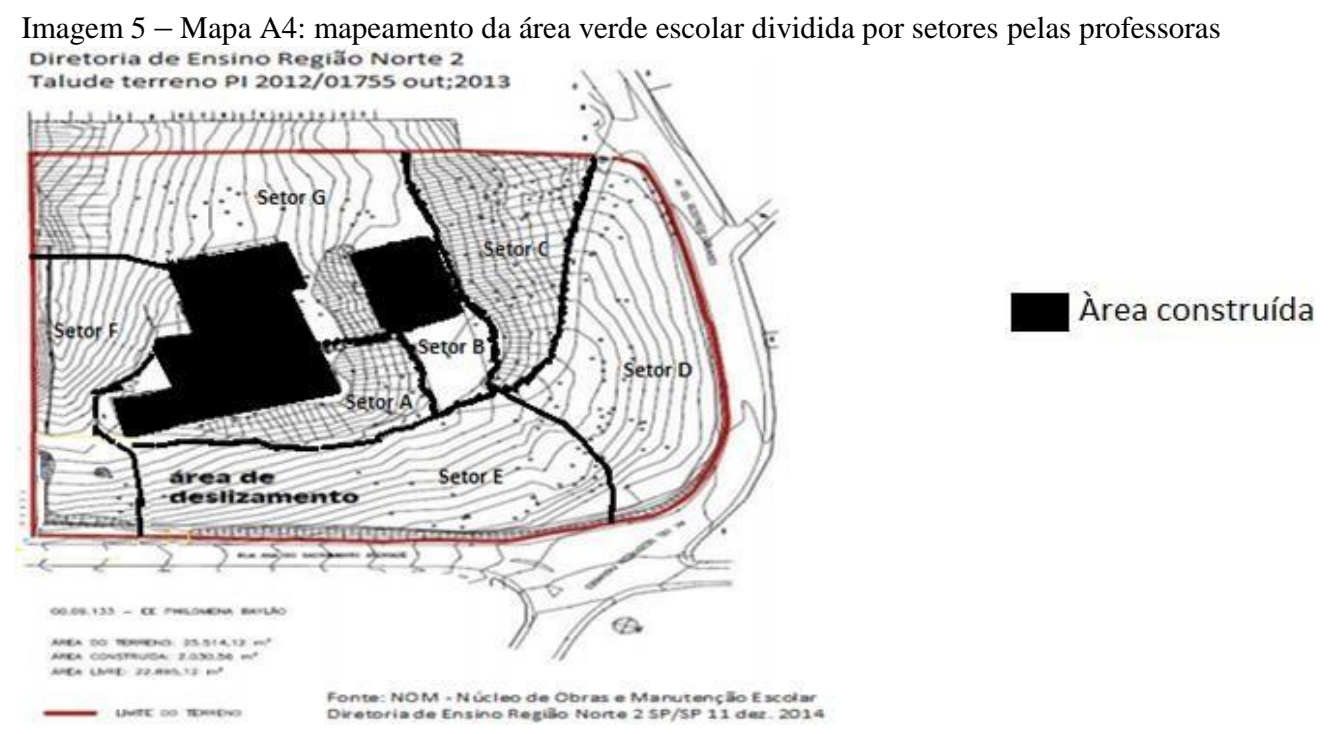

Fonte: NOM - Núcleo de Obras e Manutenção Escolar Diretoria de Ensino Região Norte 2 SP/SP. Nov. 2014.

A segunda carta cartográfica para obter a informação e a produção do conhecimento mental da área verde por parte das professoras.

Imagem 6 - Mapa A5: mapeamento mental de percepção das professoras (DAWNS, 1977; ELALI, 2003; GIBSON, 1974; GUNTHER, 2008; RIO, 1996; TUAor parte doN, 2013).
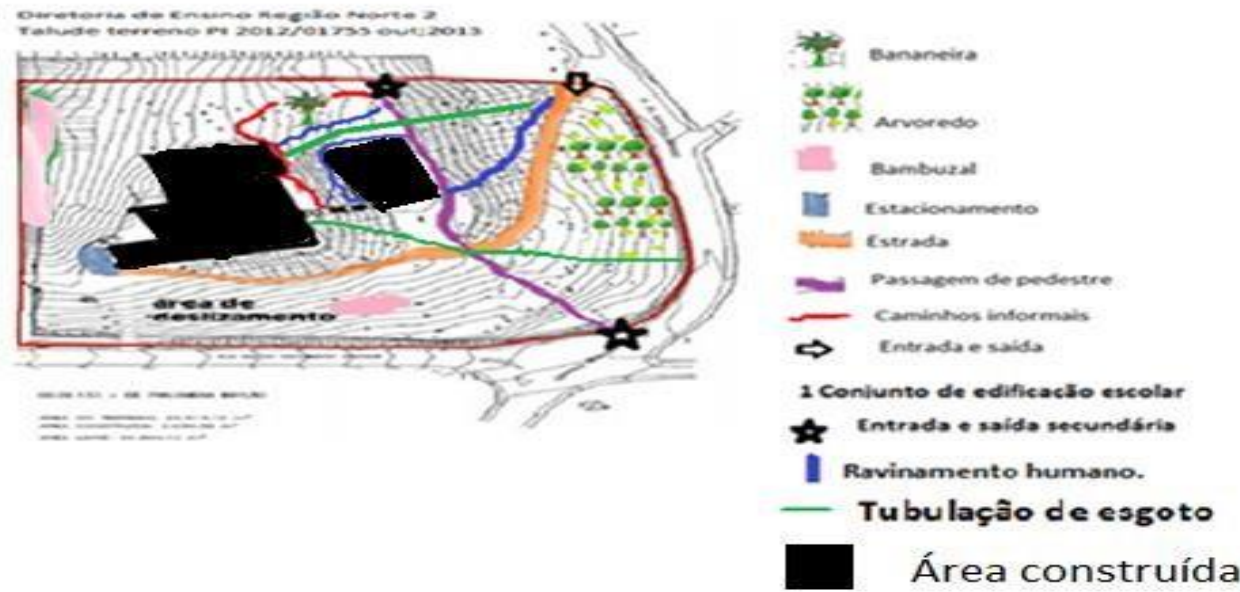

Fonte: NOM - Núcleo de Obras e Manutenção Escolar Diretoria de Ensino Região Norte 2 SP/SP. Nov. 2014. 
Já a ocupação, por período diário, na distribuição espacial dos setores identificados pelos professores, possibilitou a construção de dois gráficos centrados na pessoa-ambiente por setor.

Gráfico 1 - turno vespertino: ocupação por setor Gráfico 1

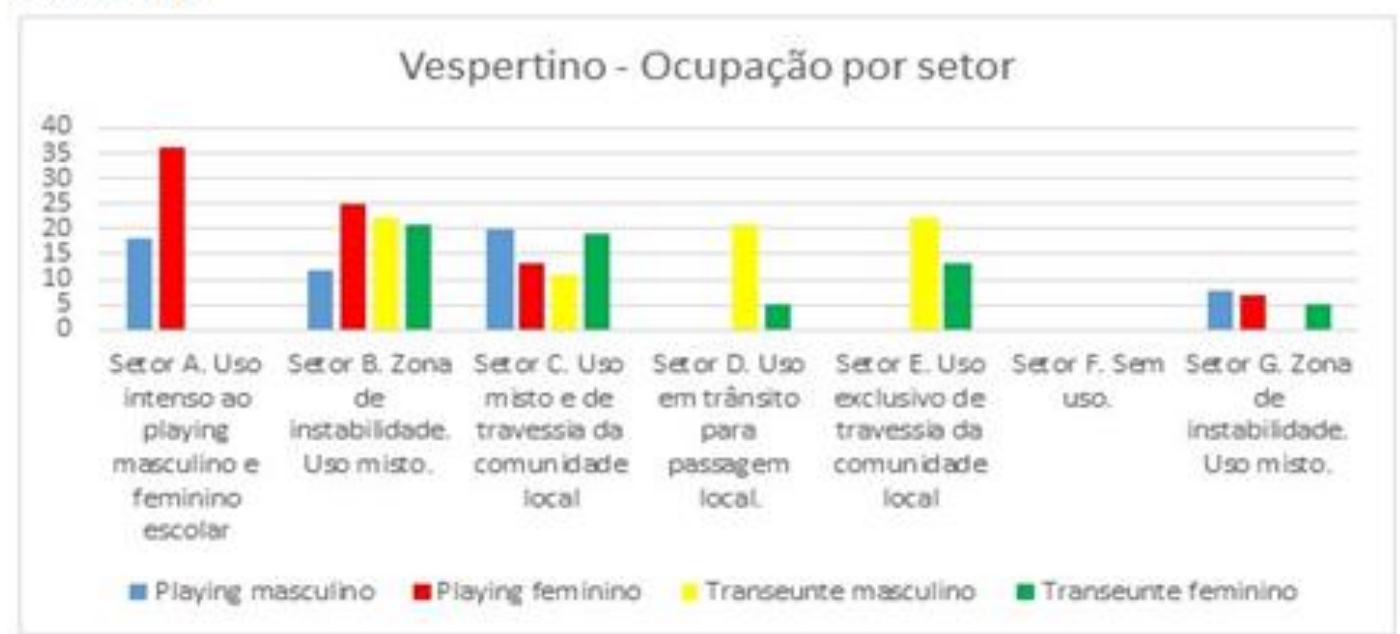

Fonte: observação set/out 2015.

Gráfico 2 - turno matutino: ocupação por setor

Gráfico 2

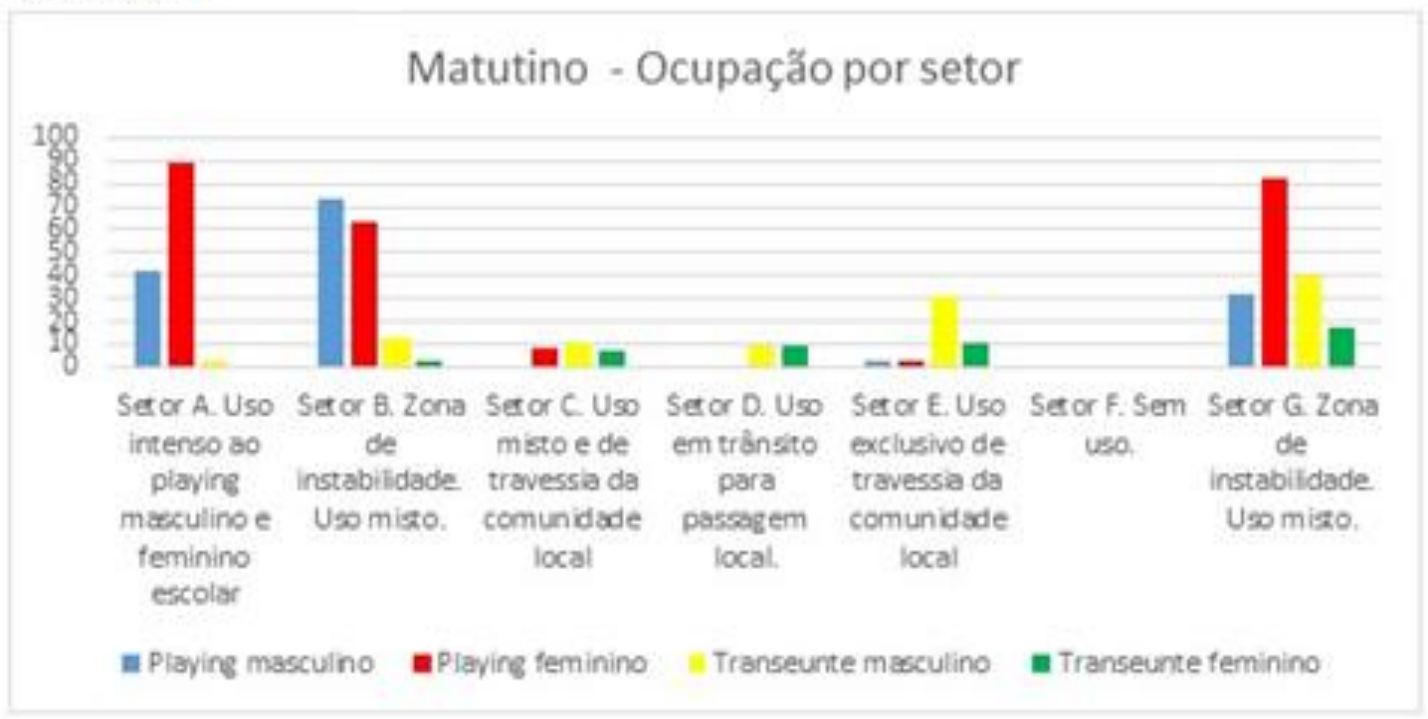

Fonte: observação set/out 2015.

A ocupação da área verde na Escola Estadual Professora Philomena Baylão, nos setores (A, B, C, D, E, F e G), apresentou diferenças de ocupação por período.

Os resultados não podem ser distorcidos por apresentarem uma possível imagem negativa ou de baixo aproveitamento da área verde escolar. Se, nos Estados Unidos e Canadá, $20 \mathrm{~m}^{2}$ /aluno é reconhecido como generoso, na Escola Professora Philomena Baylão, são $72,18 \mathrm{~m}^{2} /$ aluno no período vespertino e $40.92 \mathrm{~m}^{2} /$ aluno no matutino. Isso leva à reflexão quanto à importância dessa espacialidade devoluta. 
Essa diferente forma de ocupação entre manhã e tarde teve também fatores multicausais. O fim da primavera e o início do outono ocorreram no momento da coleta de dados. Nas manhãs, o clima ameno era convidativo para o uso das áreas verdes, já as tardes escaldantes propiciaram um recuo, e, consequentemente, a comunidade do entorno veio para dentro da área verde escolar.

Quanto à semelhança de uso, está a maior presença do playing feminino discente, liderado nos dois períodos.

Assim, os gráficos dos resultados representam o contexto da hierarquização espacial. Quanto mais distante da centralidade do edifício maior o recuo na taxa de percentual de uso e o aumento da população de transeuntes local. Isso estrutura o sistema de valores crescente e decrescente.

Inicialmente, a entrevista traz aos setores a possibilidade de relacionar sistemas de valores perceptivos em opinião ao lugar: do positivo de aconchego (agradabilidade/centralidade) indo ao negativo, desagradável (insegurança/distanciamento) em Escala Likert $(+3+2+1$ 0-1-2-3).

A partir dessa questão, pôde-se começar a compreender como os professores se posicionavam diante dos diversos setores da escola e quais os locais que preferem ou têm dificuldades de frequentar.

Ao buscar explicar o significado e o resultado dos dados nas tabelas a seguir, em escala de sistema de valores perceptíveis da área verde escolar, os professores querem dizer que, dentro da lógica de percepção pessoa-ambiente, a organização espacial de valores crescente e descrecente procura demonstrar a topofilia espacial. Nessa ordem, estão os Setores A e E respectivamente.

Tabela 2 - Escala de sistema de valores perceptíveis da área verde escolar

\begin{tabular}{|c|c|c|c|c|c|c|c|c|}
\hline \multicolumn{9}{|c|}{$\begin{array}{c}\text { ÁREA EXTERNA VERDE ESCOLAR - DIVIDIDA POR SETORES } \\
\text { Vespertino }\end{array}$} \\
\hline & \multirow{2}{*}{$\begin{array}{c}\text { Identificação } \\
\text { dos sujeitos }\end{array}$} & \multicolumn{7}{|c|}{ Identificação dos setores } \\
\hline \multirow{4}{*}{$\begin{array}{l}\text { Escala em sistema de valores } \\
\text { perceptíveis. Opinião de lugar. } \\
\text { Positivo de aconchego, } \\
\text { agradabilidade. }\end{array}$} & & $\mathrm{A}$ & $\mathrm{B}$ & $\mathrm{C}$ & $\mathrm{D}$ & $\mathrm{E}$ & $\mathrm{F}$ & $\mathrm{G}$ \\
\hline & Delta & +3 & +2 & 0 & +3 & 0 & +1 & +2 \\
\hline & Ômega & +1 & +3 & +2 & 0 & 0 & +1 & 0 \\
\hline & $\mathrm{Pi}$ & +3 & 0 & +2 & +2 & 0 & 0 & +2 \\
\hline \multirow{3}{*}{$\begin{array}{l}\text { Escala em sistema de valores } \\
\text { perceptíveis. Opinião de lugar. } \\
\text { Negativo desagradável } \\
\text { (insegurança). }\end{array}$} & Delta & 0 & 0 & -2 & 0 & 0 & 0 & 0 \\
\hline & Ômega & 0 & 0 & 0 & -2 & 0 & 0 & -3 \\
\hline & $\mathrm{Pi}$ & 0 & 0 & 0 & 0 & -3 & -3 & 0 \\
\hline \multicolumn{2}{|l|}{ Valor total } & +7 & +5 & +2 & +3 & -3 & -1 & +1 \\
\hline
\end{tabular}

Fonte: observação set/out 2015. 
Tabela 3 - Escala de sistema de valores perceptíveis da área verde escolar

\begin{tabular}{|c|c|c|c|c|c|c|}
\hline ÁREA EXTERNA VERDE ESCOLAR DIVIDIDA POR SETORES \\
Mautino
\end{tabular}

Fonte: observação set/out 2015.

Para demosntrar o entendimento perceptivo por setores, criaram-se categorias por período manhã e tarde: setor de visitação, de prática didática além-sala de aula e desejabilidade de uso, as quais foram ordenadamente tabuladas. Essas categorias geraram resultados que corroboram aos já apresentados em topofilia espacial.

Tabela 4 - Categorização da área verde por setores

\begin{tabular}{|c|c|c|c|c|c|c|c|c|c|}
\hline \multicolumn{9}{|c|}{$\begin{array}{c}\text { ÁREA EXTERNA VERDE ESCOLAR DIVIDIDA POR SETORES } \\
\text { Vespertino }\end{array}$} & $\begin{array}{c}\text { Total por setor } \\
\text { em }\end{array}$ \\
\hline & \multirow{2}{*}{$\begin{array}{c}\text { Identificação } \\
\text { dos sujeitos }\end{array}$} & \multicolumn{8}{|c|}{ Identificação dos setores } \\
\hline \multirow{4}{*}{ Visitação } & & $\mathrm{A}$ & $\mathrm{B}$ & $\mathrm{C}$ & $\mathrm{D}$ & $\mathrm{E}$ & $\mathrm{F}$ & $\mathrm{G}$ & \multirow{4}{*}{6} \\
\hline & Delta & & & & $\bullet$ & $\bullet$ & & $\bullet$ & \\
\hline & Ômega & $\bullet$ & & $\bullet$ & & & $\bullet$ & & \\
\hline & $\mathrm{Pi}$ & $\bullet$ & & $\bullet$ & $\bullet$ & & & & \\
\hline \multirow{3}{*}{$\begin{array}{l}\text { Prática } \\
\text { Ddática }\end{array}$} & Delta & $\bullet$ & & & & & & & \multirow{3}{*}{3} \\
\hline & Ômega & & & & & & & & \\
\hline & $\mathrm{Pi}$ & $\bullet$ & & & & & & & \\
\hline \multirow{3}{*}{ Desejabilidade } & Delta & $\bullet$ & & & $\bullet$ & $\bullet$ & & & \multirow{3}{*}{5} \\
\hline & Ômega & $\bullet$ & & $\bullet$ & & & $\bullet$ & & \\
\hline & $\mathrm{Pi}$ & $\bullet$ & & $\bullet$ & $\bullet$ & & & & \\
\hline \multicolumn{2}{|c|}{ Valor total } & 7 & 1 & 4 & 4 & 2 & 2 & 1 & 21 \\
\hline
\end{tabular}

Fonte: observação set/out 2015.

Tabela 5 - Categorização da área verde por setores

\begin{tabular}{|c|c|c|c|c|c|c|c|c|c|}
\hline \multicolumn{9}{|c|}{$\begin{array}{c}\text { ÁREA EXTERNA VERDE ESCOLAR DIVIDIDA POR SETORES } \\
\text { Matutino }\end{array}$} & \multirow[t]{2}{*}{ Total por setor em } \\
\hline & \multirow{2}{*}{$\begin{array}{l}\text { Identificação } \\
\text { dos sujeitos }\end{array}$} & \multicolumn{7}{|c|}{ Identificação dos setores } & \\
\hline \multirow{4}{*}{ Visitação } & & $\mathrm{A}$ & $\mathrm{B}$ & $\mathrm{C}$ & $\mathrm{D}$ & $\mathrm{E}$ & $\mathrm{F}$ & $\mathrm{G}$ & \multirow{4}{*}{4} \\
\hline & Alfa & & & & & & $\bullet$ & $\bullet$ & \\
\hline & Beta & & & & $\bullet$ & & & $\bullet$ & \\
\hline & Gama & & & & - & & & $\bullet$ & \\
\hline \multirow{3}{*}{$\begin{array}{c}\text { Prática } \\
\text { Didática }\end{array}$} & Alfa & & & & & & & & \multirow{3}{*}{2} \\
\hline & Beta & & & & & & & $\bullet$ & \\
\hline & Gama & & & & & & & $\bullet$ & \\
\hline \multirow[b]{3}{*}{ Deseabilidade } & Alfa & & & & & $\bullet$ & $\bullet$ & $\bullet$ & \multirow{3}{*}{5} \\
\hline & Beta & & & & $\bullet$ & & & $\bullet$ & \\
\hline & Gama & & & & $\bullet$ & & & $\bullet$ & \\
\hline \multicolumn{2}{|c|}{ Valor total } & 6 & 0 & 0 & 4 & 1 & 2 & 8 & 21 \\
\hline
\end{tabular}

Fonte: observação set/out 2015. 
Tabela 6 - Tabulação de escala e categorização

\begin{tabular}{|l|l|l|l|l|l|l|l|}
\hline \multicolumn{2}{|c|}{ Tabelas } & \multicolumn{5}{c|}{ Setores } \\
\hline $\begin{array}{l}\text { Tabela 2 Escala de sistema de valores perceptíveis da } \\
\text { área verde escolar }\end{array}$ & A & B & C & D & E & F & G \\
\cline { 2 - 8 } & +7 & +5 & +2 & +3 & -3 & -1 & +1 \\
\hline $\begin{array}{l}\text { Tabela 3 Escala de sistema de valores perceptíveis da } \\
\text { área verde escolar }\end{array}$ & +6 & +1 & -2 & +4 & 0 & +1 & +5 \\
\hline Tabela 4 Categorização da área verde por setores & 7 & 1 & 4 & 4 & 2 & 2 & 1 \\
\hline Tabela 5 Categorização da área verde por setores & 6 & 0 & 0 & 4 & 1 & 2 & 8 \\
\hline Valor Total & 26 & 7 & 4 & 15 & 0 & 4 & 15 \\
\hline
\end{tabular}

Fonte: observação set/out 2015.

Tabela 7 - Classificação geral em lugar e paisagem da área verde escolar

\begin{tabular}{|c|c|c|c|c|c|c|c|}
\hline \multicolumn{8}{|c|}{ Setores } \\
\cline { 2 - 9 } & $\mathrm{A}$ & $\mathrm{B}$ & $\mathrm{C}$ & $\mathrm{D}$ & $\mathrm{E}$ & $\mathrm{F}$ & $\mathrm{G}$ \\
\hline Classificação & $1 .^{\circ}$ & $3 .^{\circ}$ & $4 .^{\circ}$ & $2 .^{\circ}$ & $5 .^{\circ}$ & $4 .^{\circ}$ & $2 .^{\circ}$ \\
\hline
\end{tabular}

Fonte: observação set/out 2015.

Restando quatro questões $(2,3,4$, e 6 - Apêndice A, p. 70) para finalizar a análise de resultado, optou-se em apresentá-las individualmente. Isso facilita o entendimento e a metodologia. Em todas as questões, a análise, transcrição/degravação, foi realizada de acordo com as falas dos sujeitos em situação proposital walking around.

$\mathrm{Na}$ organização do ambiente em setores verdes, as professoras, no quesito sensasões e reações como outros atributos constitutivos da percepção, responderam sempre em primeira pessoa, e as perguntas foram feitas na terceira. Isso se deu pela forma da metodologia usada em pesquisa pessoa-ambiente, em que busca aproximação respondente e pesquisador, estabelecendo um relacionamento de confiança recíprocra.

Em apontamento, o setor D, na tabela a seguir, quanto aos atributos constitutivos da percepção da área verde escolar, por setor, apresentou maior resultado de conexão com a natureza, pois as percepções foram mais homogêneas tanto em sensações quanto em impressões e reações. Vale ressaltar que ele é lindeiro, margeia com a avenida (Imagem 5, p. 47). Assim, nas falas das professoras, a grande área verde "desperta sair da monotonia, devido à beleza dos elementos naturais, que dão sensações de paz e tranquilidade, possibilitando trabalhar com brincadeiras e práticas esportivas, favorecendo assim a reconstrução do local”. Isso está na desejabilidade.

Segue a tabela com a seleção de atributos que possibilitam correlacionar a apresentação de percepção pessoa-ambiente na topofilia do lugar por setores. 
Tabela 8 - Atributos constitutivos da percepção por setores da área verde escolar

\begin{tabular}{|c|c|c|c|}
\hline Sujeitos & Setores & $\begin{array}{l}\text { Questão } \mathbf{2} \text { - Cita as sensações que } \\
\text { teria um cidadão comum visitando a } \\
\text { área externa por você identificado? }\end{array}$ & $\begin{array}{c}\text { Questão 3-O que causaria maior (es) } \\
\text { impressão (ões) nesse cidadão e como } \\
\text { ele reagiria nesse setor? }\end{array}$ \\
\hline \multirow{3}{*}{ Delta } & $\mathrm{D}$ & $\begin{array}{c}\text { "acho que sensações naturais, belezas } \\
\text { naturais" }\end{array}$ & "local de práticas esportivas" \\
\hline & $\mathrm{E}$ & "abandono, horroroso" & "melhoria do local, mais segurança" \\
\hline & G & "parece que está em uma chácara" & $\begin{array}{l}\text { "trabalhar o solo com alunos dos } 6^{\circ} \mathrm{s} \\
\text { anos, é um lugar rico, riquíssimo!" }\end{array}$ \\
\hline \multirow{3}{*}{ Ômega } & A & "uso da horta em pratica didática" & "cuidar mais do solo" \\
\hline & $\mathrm{C}$ & "paz, tranquilidade" & "usar para brincadeiras" \\
\hline & $\mathrm{F}$ & "alto, grande área para trabalhar" & $\begin{array}{c}\text { "poxa!! O pessoal não trabalha esse } \\
\text { espaço" }\end{array}$ \\
\hline \multirow{3}{*}{$\mathrm{Pi}$} & A & $\begin{array}{l}\text { "você pode usar a horta com fins } \\
\text { didático" }\end{array}$ & "aproveitar melhor" \\
\hline & $\mathrm{C}$ & "contemplação, quintal de casa" & "usar para atividade extra classe" \\
\hline & $\mathrm{D}$ & "paz, tranquilidade, relaxamento" & "usar com brincadeiras" \\
\hline \multirow{3}{*}{ Alfa } & A & "a horta atrai o olhar" & $\begin{array}{l}\text { "ter grande quantidade de plantas para } \\
\text { trabalhar com os alunos" }\end{array}$ \\
\hline & $\mathrm{F}$ & $\begin{array}{l}\text { "canto dos pássaros, proteção da } \\
\text { vida" }\end{array}$ & "lugar quente e úmido" \\
\hline & $\mathrm{G}$ & $\begin{array}{l}\text { "estar em sítio, frutas, sementes, } \\
\text { como se estivesse numa floresta" }\end{array}$ & "curiosidade" \\
\hline \multirow{3}{*}{ Beta } & A & E"u pensei no uso com os alunos", & $\begin{array}{c}\text { "de um lugar que pode trabalhar com os } \\
\text { alunos" }\end{array}$ \\
\hline & $\mathrm{D}$ & "vista privilegiada" & $\begin{array}{c}\text { "subir e descer rampas, reconstruir o } \\
\text { local" }\end{array}$ \\
\hline & G & $\begin{array}{c}\text { "diversidade de plantas, } \\
\text { aprendizagem das espécies vegetais" }\end{array}$ & $\begin{array}{l}\text { "trabalhar os elementos da paisagem } \\
\text { com os alunos" }\end{array}$ \\
\hline \multirow{3}{*}{ Gama } & A & $\begin{array}{c}\text { "área para trabalhar, mais falta } \\
\text { material" }\end{array}$ & $\begin{array}{c}\text { "não da importância, estão acostumados } \\
\text { com a área" }\end{array}$ \\
\hline & $\mathrm{D}$ & $\begin{array}{c}\text { "surpresa com a força do verde, } \\
\text { diferente espécie de planta da região" }\end{array}$ & $\begin{array}{l}\text { "Olha é nossa!! Será que pode fazer } \\
\text { algo, despertar a monotonia". }\end{array}$ \\
\hline & G & $\begin{array}{l}\text { "estar em uma área diferente da } \\
\text { cidade de São Paulo" }\end{array}$ & $\begin{array}{l}\text { "lugar incompleto, monótono que busca } \\
\text { algo para fazer" }\end{array}$ \\
\hline
\end{tabular}

Fonte: observação set/out 2015.

Ao solicitar que o sujeito captasse por fotografia uma imagem - questão 4 (Apêndice A, p. 70) - com referência, relevância, importância em existência local, com alto grau de representatividade em algum marco ou símbolo no setor, exigia tomada de decisões. Essa exigência metodológica levou necessidade de criar procedimento em agrupamento de ordem e semelhança para a classificação das imagens, buscou-se, com isso, simular, avaliar ou decodificar a percepção espacial no setor.

Das cinco imagens produzidas, três se enquadraram, apresentando coerência quanto aos elementos próprios da investigação, valor e significado em julgamento na temática da pesquisa, similaridade de reflexão e percepção quanto à paisagem e ao lugar. As imagens são dos sujeitos Alfa, Beta e Gama, Fundamental II, período da manhã em que a ocupação se deu de forma mais intensa. 
Feito o agrupamento e ordenamento, o resultado demonstrou valores crescentes (imagem fotográfica do mamoeiro e do pé de funcho), decrescente (imagem fotográfica do entulho) e entram como apreensão do local aos estímulos educativos. O ponto focal para a produção das imagens fotográficas escolhido pelos sujeitos foi o do interior da horta.

Em condições gregárias, as três selecionadas por exigência do método foram ordenadas por: ponto focal, silhueta e padrões funcionais segundo Cullen (1971).

Tabela 9 - Agrupamento e ordenamento de imagens

\begin{tabular}{|c|c|c|c|}
\hline \multicolumn{4}{|c|}{ Setor A - Ponto focal em observação e ordenamento das imagens } \\
\hline Sujeitos & Ponto focal & Silhueta & Padrões funcionais \\
\hline Alfa & O mamoeiro & \multirow[b]{3}{*}{$\begin{array}{l}\text { Na silhueta dos pontos } \\
\text { focais, são as alusões } \\
\text { conferidas. Marcos, } \\
\text { símbolos, local e } \\
\text { referência com } \\
\text { relevância e } \\
\text { representatividade. Esses } \\
\text { adjetivos são o que gera, } \\
\text { promove, fomenta e } \\
\text { potencializa as } \\
\text { atividades educacionais. }\end{array}$} & \multirow[b]{3}{*}{$\begin{array}{l}\text { Os padrões para a análise funcionais se justificam } \\
\text { por critérios crescente de valores apresentados, em } \\
\text { função das práticas didáticas ao uso. O excesso de } \\
\text { entulho, barreiras, gradeamento, que dificulta a } \\
\text { mobilidade educativa, aparece em uma única } \\
\text { imagem (o entulho). As demais, a apreensão esta no } \\
\text { hortifruti (mamoeiro e o pé de funcho), como } \\
\text { elemento que agrega outros lugares as práticas ao } \\
\text { ensino-aprendizado. }\end{array}$} \\
\hline Beta & O entulho & & \\
\hline Gama & $\begin{array}{l}\text { O pé de } \\
\text { funcho }\end{array}$ & & \\
\hline
\end{tabular}

Fonte: observação set/out 2015

A sexta e última questão analisada como resultado criou uma alusão de semáforo projetado em três fases (vermelho, amarelo e verde) para a tomada de direção ao encontro com a área verde livre escolar do entorno predial. Da amostra (Beta, Gama, Delta, Ômega e Pi) pesquisada, como percepção 83,3 \% tiveram a cor verde ao uso do ensino aprendizado em situação de transferência didática transdisciplinar; "verde é o sinal de segurança".

Essas cores são de simbologias que, frequentemente, nos darão os efeitos emocionais da percepção e foram apresentadas por Tuan $(2012 ; 2013)$ como oposições binárias. Desde os anos 600-900 d.C., que se vem criando a visão clássica de cores no Ocidente pelos índios Pueblos, do sudoeste americano, ou no Oriente, com os chineses, indianos e indonésios ou ilhas do Pacífico (TUAN, 2012 e 2013).

A mente humana parece estar adaptada para organizar os fenômenos não só em segmentos, como arranjá-los em pares opostos. Fragmentamos o espectro das cores em faixas discretas e então vemos "vermelho", como o oposto de "verde". O vermelho é sinal de perigo, e o verde é o sinal de segurança. Os semáforos usam essas cores pela rapidez com que lemos as mensagens. Em outras culturas, as cores podem ter uma associação emocional a algo diferente, mas permanece válido o ponto de vista geral, mormente e tendência da mente humana para selecionar pares entre 
segmentos percebidos no continuum da natureza e atribuir significados polarizados [...] selecionamos a cor amarela para significar "atenção", não "pare" ou siga; e neste caso o amarelo, no espectro das cores, é a faixa de comprimento de onda intermediaria entre o vermelho e o verde, e não simplesmente uma cor arbitraria escolhida. $\mathrm{O}$ amarelo medeia a ideia de centro e reconcilia com as tendências binarias entre o vermelho e o verde (TUAN, 2012, p. 34 e 35) [...] A sensibilidade humana para as cores manifesta-se em idade muito precoce [...] e desempenha um papel muito importante nas emoções humanas, podem constituir os primeiros símbolos do homem. [...] As cores primárias designam emoções fortes (TUAN, 2012, p. 45).

Vence o verde, $83,3 \%$. Esse alto percentual de sujeitos atestam, no resultado final, que se sentem seguros nas áreas verdes do entorno escolar. O verde é segurança. 


\section{DISCUSSÃO}

A área verde da Escola Estadual Professora Philomena Baylão foi dividida em sete setores (A, B, C, D, E, F e G) de acordo com a percepção dos seis sujeitos investigados na pesquisa (Imagem 5, p. 47). Setor A apresentou maior potencial para o uso de possibilidades didáticas, confirmado pelos vestígios encontrados no momento real da observação em que ocorria a coleta de dados e embem como pelas percepções fornecidas pelos professores. Isso representa $14 \%$ dos setores de área verde em uso. Outra relevância, não em uso, porém em apontamento de desejo, tem o Setor D, devido aos atributos constitutivos da percepção por setor da área verde escolar.

Ao critério de escolha e entendimento de percepção de lugar - da área verde escolar -, significa que as tabelas Escala de sistema de valores perceptíveis da área verde escolar (2 e 3, pp. 49-50 ) e Categorização da área verde por setores (4 e 5, p. 50), em interação pessoaambiente, foram determinantes no critério de percepção de espaço como opinião de lugar em condições da topofilia. Valores crescentes de aconchego, alto, supremo e de centralidade, e indo ao decrescente, desagradavel, baixo e periférico, na Escola Estadual Philomena Baylão, ficaram identificados do Setor A indo para o Setor E (Tabela 6, p. 51).

Assim, para descrever a rejeição ou não no resultado dos dados, o tipo de discussão que a análise permitiu compreender é a que as pessoas tendem a se estruturarem no espaço em que elas estejam no centro, partindo de um estado de sentimento e aconchego (TUAN, 2013).

A classificação geral por setores (Tabela 7, p. 51) propiciou aprofundar a discusão de resultado, ao colocar todos os instrumentos ou pasteusp em serviço exploratório quanto à percepção de a área verde presente na escola ao ensino-aprendizado. Assim, ao sintetizar e condensar os dados por setores de área verde escolar, os resultados apontam para duas modalidades de discussão qualitativa no método de percepção de lugar pessoa-ambiente: Pertinência Avaliativa, para o Setor A, e Contraste em Conduta, para o Setor E, por período manhã e tarde (RIO, 1996), apresentadas a seguir.

- Pertinência Avaliativa - Setor A

Procura-se nessa pertinência, compreender a importância da área verde escolar como espaçode práticas didáticas no uso do ensino aprendizado em percepção pessoa-ambiente. $\mathrm{O}$ Setor A permitiu identificar evidências em alguns padrões principais e característicos no que concerne aos lugares que inspiram sentimentos topofílicos (RIO, 1996; TUAN, 2013) classificação geral em lugar e paisagem da área verde escolar (Tabela 7, p. 51). 
Região alta e anexa ao prédio escolar, o Setor A, além da proximidade, possui proteção e aconchego. Boa parte plana, fácil contato visual $180^{\circ}$ de visão, possui elementos que mantêm a observação e o controle - campo de visão topográfico -, pois está à frente do prédio escolar, expressiva altura de 12 metros acima do nível da rua, onde se localiza a horta sscolar. Assim, o Setor A tornou-se um lugar de significado onde a organização espacial estruturou seu uso pedagógico. Esses fatos revelam que a forma de ocupação ocorre para os sujeitos de maneira que estes se veem no centro da espacialidade escolar, estruturando-se, a partir daí, os valores crescentes e decrescentes.

A redação obedece, em sua descrição, à discussão de dados com as condições inerentes ao momento da coleta. A metrópole paulistana teve pico recorde de chuva, frio e calor em curtíssimo período de horas. O quesito calor (somente nos registros de diário de campo 'temperatura') influenciou no resultado da pesquisa. O intenso calor da tarde fazia exaustivas as saídas discentes das salas de aula ou 'espaço panótico', com o mau tempo da transição de estação do ano, fim da primavera e início de outono, o inverso experienciava o matutino, o clima era aprazível e convidativo às áreas livres.

Enquanto isso, levada à pressão, carência e falta de espaços arborizados, a área verde escolar, no período vespertino, passa a ser preferência da população local - os transeuntes locais -. A escola Estadual Professora Philomena Baylão fica nos arrabaldes da metrópole, conurbada a Guarulhos, segunda maior cidade do estado, entregue à própria sorte. Seus portões de entrada não existem. Há marcas de seus vestígios (Imagem 1, p. 38).

Pela investigação dos vestígios de comportamento centrado no ambiente e na pessoa, os setores do vespertino revelaram:

a) baixo índice de uso durante a pesquisa;

b) percentual de ocupação de playing discente escolar masculino e feminino, abaixo de transeunte local masculino e feminino;

c) uma relação direta; falta da presença discente em atividades além-sala: aumento excessivo da população local em território escolar;

d) fatores multicausal como o clima e a temperatura influíram nesse processo. A pesquisa ocorreu na mudança de estação, saída da primavera e entrada do outono;

e) relevância na forma em que os transeuntes ocupam os $50 \%$ dos setores. Eles se misturam com os discentes em uso coletivo; lazer e esporte, bater-papo, dão e levam recados. Todos estão dispersos;

f) vulnerabilização de pessoas no processo de ensino pedagógico para com as áreas externa; e 
g) uma percepção do grande numero de transeunte local, são fatores negativo em ameaça. Isso desmotiva o uso.

Diferentemente a esse cenário, os setores matutinos em percepção de campo pessoa-ambiente apresentaram:

a) maior taxa de ocupação e uso durante a pesquisa, com predominância playing feminino;

b) uma maior expansão de ocupação por setores ao playing discente. Esse fato faz os transeuntes permearem de forma relacional ao playing discente até em áreas afastadas.

c) redução do uso não discente 'transeuntes homens e mulheres' em área verde escolar. A escola ocupando a escola. Relação de efeito direto entre o aumento da presença discente em território escolar. A base comparativa de estudo foi entre os períodos manhã e tarde.

- Contraste em Conduta - Setor E

Essa análise abarca um conjunto de informação de fenômenos que se naturalizam por acordos sociais ou por nossa capacidade de transformar em verdade sólida, o que somente existia no imaterial, ainda não pesquisado, a percepção da área verde escolar em um conjunto detalhado por investigação de resíduo ou vestígio da arqueologia do comportamento. Percepção pessoa-ambiente.

O objetivo no quesito Contraste em Conduta, no Setor E, foi compreender a importância de suas áreas verde como espaço de práticas didáticas no uso para o ensino aprendizado na escola. O Setor E não é fronteiriço ao prédio escolar, é o maior e mais distante com uso exclusivo dos transeuntes. Isso diferencia na forma de uso e permanência comportamental. Destaca-se entre os demais pela maior rota sinuosa interna com meandros de uso devido aos amplos terraços da escadaria em declive. Aqui, o usuário perde-se na visão do controle e da disciplina devido ao distânciamento da centralidade predial. O Setor E ficou em última posição na classificação geral partindo de um estado de sentimento de aconchego e indo para o desagradável em valores crescentes e decrescentes (Tabela 7, p. 51).

Quanto aos vestígios de comportamento centrado no lugar, eles são imensos e revelam preservativos de encontros amorosos e fortuitos, vestígios de embalagens de alcaloides, garrafas quebradas, fósforo e isqueiros quebrados, sinais de incêndios nos troncos das árvores, corte de árvores, grafite e pichação com expressões de marcas e memórias. Isso tudo somado ao excessivo descarte de embalagens dos hábitos alimentares de comportamentos manifestados. Isso revela forças que agravam os valores ambientais. 
Assim, o Setor E vespertino, no quesito Contraste em Conduta, uso e práticas de transferência didática em situação de aprendizagem transdisciplinar, foi reconhecido como não lugar de território didático, em diferentes dias e horários pareceram preocupantes, revelando:

a) um setor com alto percentual de ocupação por transeunte masculino local; nas quatro formas identificadas.

b) um recuo da ocupação do playing escolar próximo ao edifício. Para explicar a relação de causa e efeito, os dados obtidos para o comparativo foram entre manhã e tarde.

c) um comportamento de uso voraz e sempre em expansão feito pelos transeuntes masculinos, registrados em mais três Setores B, C e D, onde estão os nós, vias e caminhos de passagem (Gráfico 1, p. 48).

Diferentemente desse cenário, no matutino apercepção de campo pessoa-ambiente pela investigação apresentou:

a) uma preocupante presença de discente masculinos e femininos relacionando com os transeuntes local.

Os resultados não refletem que somente os professores são os únicos corresponsáveis, que somente essa escola seja dessa forma, ou que os sujeitos tenham também a mesma percepção. Quando é apresentada a área por setores, a categoria 'desejabilidade' confirma haver possibilidade na pespectiva de expanção em ações pedagógicas a outros setores. Setor D (Tabela 8, p. 52).

Assim, a discussão dos dados não refuta ao referencial teórico, mas apresenta miopia do quão distante estão as áreas verdes escolares voltadas para o aporte do cotidiano além-sala de aula quando não setorizada devido ao baixo índice de uso identificado.

Face ao baixo uso da área verde, a Educação Ambiental, é responsável no momento em que subsidia informações além de ser elo comum a outras disciplinas. Isso pode fomentar propostas em que as áreas verdes livres não passam a serem hábitos desapercebidos. Dar a elas caráter de território transdisciplinar contribuitiva em práticas além-sala de aula.

\begin{abstract}
A procura da realidade é operacional: busca-se a linguagem [...], as representações de valores, os hábitos e as expectativas construídos pela vida diária é disperso em marcas e sinais que passarão esquecidos ou inadvertidos, se não forem resgatados pela observação e atenção do pesquisador. (RIO, 1996, p. 66).
\end{abstract}

Fatores de percepção em contexto do Iave na formação contínua que respalda o discente quanto à Educação Ambiental não chegaram até a abrangência da prática pedagógica em ecologia humana do sujeito no contexto da literatura proposta. Na Ficha de Identificação, Apêndice A, p. 70, dos graduados, $100 \%$ responderam que não participaram ou estiveram nos 
últimos dois anos em eventos que abordam as áreas verdes escolares com propósito temático ou similar.

Isso revela pouca atenção dada aos espaços verdes escolares como parte na formação continuada docente. Seja em discussões semanais no horário de trabalho coletivo na escola, sejam palestras na Diretoria de Ensino Norte 2, sejam em cursos na Escola de Formação de Professores da Secretaria Estadual de Educação do Estado de São Paulo.

As Áreas Verdes Escolares ainda não têm lugar em um programa de ensino, não são desenvolvidos programas de governo, revelando escassa possibilidade de política pública e uma baixa percepção do sujeito quanto a externalidade da sala de aula.

Os vestígios ambientais ou arqueologia de comportamento em espaço verde de entorno predial fronteiriços à rua e calçada revelam que $86 \%$ dos setores permanecem área devoluta, ou seja, com pouca experiência em conduzi-la ao uso pedagógico, não revelando o verdadeiro potencial a ser desenvolvido com esses lugares para as práticas didáticas.

São poucos os estudos, nessa linha, que abordam as áreas verdes escolares e que buscam adicionar mais espaços à disposição da criança, afirmando que elas desenvolvem com mais facilidade e frequência as habilidades mentais devido aos serviços ecossistêmicos a que se beneficia. Alguns deles: melhoria na qualidade de vida, redução da poluição, diminuição da poluição sonora, diminuição das temperaturas, cortina de absorção dos raios, sombreamento, valorização visual e ornamental do espaço físico bem como neutralizador de efeitos nocivos na população escolar. Esses elementos podem resultar em vantagem para o capital mental da população escolar em aprendizagem ao ar livre.

Trabalhos publicados sobre a exposição ao verde no reconhecimento de áreas escolares, numa estrutura não formal de ensino, ainda estão fora do cotidiano educativo das escolas, distantes como campo de investigação e não reconhecido pela historiografia educacional. As escolas estaduais na capital paulista estão longe desse momento, porém são em variadas formas que surgem e se efetivam essas áreas ecolares.

$\mathrm{Na}$ Dinamarca, a utilização do espaço exterior (natureza) 'é uma tradição no desenvolvimento de competências e aprendizagens das crianças', já na Noruega o papel da educação em contexto externo 'é tão primordial que estão explícitos em documentos oficiais'. Esses países acreditam que o movimento das crianças a permanência em espaços exteriores outdoor schooling faz o investimento nesse novo tipo de escola deixa antever, num futuro próximo, o provável aumento de respostas centradas nos exteriores (FERREIRA, 2015, p. 76).

Os países escandinavos defendem, há gerações, a importância da natureza e do espaço exterior na infância e na educação de crianças e jovens (BENTSEN, MYGIND; RANDRUP, 
2009 apud FERREIRA, 2015, p. 73). Em pesquisa, Ferreira (2015) mostra até a cultura de uso e permanência das crianças nos contextos educativos externos, independentemente das condições climatérica: neve, chuva forte ou vento. A permanência no exterior varia, em média, entre duas a quatro horas no outono e no inverno (exceto quando ocorre temperatura entre $-10^{\circ}$ $\mathrm{C} \mathrm{e}-20^{\circ} \mathrm{C}$, nas quais as crianças permanecem no exterior apenas quinze a vinte minutos), sendo superior a seis horas na primavera e no verão (LYKLETT, 2005; MOSER; MARTINSEN, 2010 apud FERREIRA, 2015). São Paulo, capital, pode usufruir muito da tropicalidade em seu traçado escolar. Aqui passa o Trópico de Capricórnio.

Após descrição do enquadramento dos espaços exteriores em escolas dos países nórdicos (Dinamarca e Noruega),

[...] pode considerar a existência de dois subgrupos com concepções distintas: Portugal,

Reino Unido e EUA apresentam uma perspectiva assistencialista dos espaços exteriores, direcionada para as crianças socioeconomicamente desfavorecidas, enquanto os países nórdicos promovem os espaços como uma parte essencial para a vida das crianças, jovens e adultos. Estas diferenças têm, inevitavelmente, implicações na interação criança-espaços (FERREIRA, 2015 p. 80).

Outro trabalho que vem ao encontro ou semelhanças foi o publicado pela revista científica Proceeding of the National Academy of Sciences, o estudo Green spaces and cognitive development in primary schoolchildrens, em livre tradução "espaço verde entorno das escolas pode aumentar a capacidade mental dos alunos da escola primária" (DADVAND et al. 2015).

Esse estudo revela que o verde entorno das escolas aumenta a capacidade mental cognitiva em contato com a natureza, que desempenha um papel fundamental e insubstituível no desenvolvimento do cérebro das crianças que, ao manipular de forma contínua, atualiza informações com mais facilidade, registra melhor a capacidade da memória, redução na desatenção, independentemente da etnia, da escolaridade familiar. Esse estudo mostra uma associação benéfica entre a exposição das crianças em áreas verdes e o desenvolvimento cognitivo (PDADVAN et al. 2015). 


\section{CONCLUSÕES}

Aquilo que também pode fazer parte do universo escolar quando estamos tratando de percepção, a área livre verde do entorno predial, foi abordado nessa pesquisa como experiência espacial humana, centradas, em específico, nas relações humana. Isso trouxe informações de que carências são oriundas de múltiplas privações socioafetivas de contato com o espaço físico cercado por elementos naturais.

$\mathrm{O}$ alto percentual de déficit de uso no Iave (86\%) na Escola Estadual Philomena Baylão revela a necessidade de uma Educação Ambiental com linguagem pedagógica que possa assumir, de fato, o uso das áreas verdes como ambientes de ensino-aprendizagem em abordagem para compreensão, entendimento e dimensão pessoa-ambiente na escola, estabelecendo intervenções que podem contribuir para o fomento ao uso pedagógico da área verde escolar.

Esse estudo, que teve centrado em uma única escola pública na capital paulista, não se pode ter dúvida quanto ao cenário, em tudo semelhante, que poderá encontrar. Também, não se pode generalizar do ponto de vista investigativo, mas saber que o empírico já permite deter, a partir da docência, direção, supervisão, professores em oficina pedagógica, encontros, seminários, conversas informais e fala de aluno, revelando a probabilidade das areas externas verdes estarem frequentemente esquecidas nas escolas da Diretoria Norte 2 é elevadíssima.

A Escola Estadual Professora Philomena Baylão, e outras tantas podem ter como modelo pedagógico áreas externas que objetivam melhoria no processo cognitivo de aprendizagem dos indivíduos por meio da reflexão, da sistematização e da produção de conhecimento e que não limitam o maior tempo do sujeito aprendente a sala de aula. Isso já foi apresentado na percepção dos professores.

Tratando-se de uma metodologia expressa em pessoa-ambiente, foi possível medir, cartografar e normatizar padrões de usuários hierárquicos e classificados. Para esse efeito, foram utilizados parâmetros abertos em convenções, advindos da interpretação por diversos sujeitos atuando em diferentes linhas do saber.

Nos Setores devolutos, há diversidade de material a ser explorado. Uma rica fauna e flora que podem ser utilizadas e manipuladas para as práticas didáticas. Ao descortinar a vegetação do entorno escolar, potencializa-se mais o processo acadêmico científico de descoberta de seus docentes e discentes em playing escolar. Da escola, é visível, numa pedreira, a imensa cratera da Serra da Cantareira. Isso explora além da geografia, demanda de 
insumo na construção da cidade, do perigo e das explosões de suas rochas, é possível desenvolver o gosto pela física; da mata, a fito Bbotânica; das chácaras, a percepção da economia solidária.

Além dessa externalidade, após a pesquisa de vestígios no ambiente, é possível buscar no interior da área verde escolar :

- preservar e desenvolver o cultivo das espécies frutíferas existentes no território dos Setores A, C, E, F e G;

- reduzir, a partir da Educação Ambiental Transdisciplinar, o descarte de lixo em todos os setores;

- recolher ferragens de mobiliário escolares sem uso para estimular a educação no Setor F;

- realizar prevenção antidroga e gravidez indesejável na adolescência, diante dos encontros amorosos atestados por vestígios de comportamento no Setor E.

Apresentar essa paisagem de lugar no presente escolar é buscar sempre abertura à (re)construção. Isso não é mito factível, deve ser apenas a criação de um conjunto de propostas e ações que ampliam o uso dos setores, no que eles apresentam em potencialidades, perfis e demamda.

Todos os setores podem servir como espaços didáticos, derivados por traçado que faz referência a constituir e categorizar experiência, que ressaltam o verdadeiro significado da natureza das áreas verdes do entorno predial escolar.

Essa escola pode se tornar, a partir de percepções ambientais, tanto pela sua área como pelos poderes constituídos, corresponsabilidade de uso dando fuga as impossibilidades que é o Environmental Numbness, ou seja: apatia ao lugar, das incompletudes, das impermanências e de irrealizações supostamente com tudo que existe no local a explorar como o campo da imagem ou das representações que vinculam espaços em práticas didãticas. Isso elevaria as categorias setoriais de percepção crescente de valores positivos e abaixaria os índices decrescentes de valores negativos, repulsa ao uso.

A Escola Estadual Philomena Baylão pode tornar seus espaços mais humanizados ao valorizar seu Iave de 25.562,49 $\mathrm{m}^{2}$. Modelo e lugares com tradição já citados anteriormente são referências potenciais de possibilidades.

A partir das observações e das notações no diário de campo, a rota sinuosa interna de uso revela aconchegantes meandros, amplos terraços de escadaria em declive, caminhos, curvas e travessas, notadamente com necessidade de: (a) vaporizadores e bebedouros em dinâmica da ocupação devido aos verões escaldantes; (b) instalações de ecobag seletiva; (c) 
adequação ao descarte de sobras da merenda escolar, pois os cães que vagueiam pela área procuram satisfazerem suas necessidades; (d) correção no vazamento do sistema de esgoto que impede a plenitude de uso dos Setores B e G (Iamgem 6, p. 47), causando odores e contaminação; (e) ampliação e democratização da rede móvel disponível para alunos em campo de pesquisa; (f) criação de um bicicletário para amparar aqueles que fazem uso ou estimulando esse meio de transporte; (g) distribuição de placas educativas/informativas e avisos da fauna, flora e dos setores de uso para esporte, jogos interativos, estudos, pesquisa e ensaio; (h) fortalecer ao longo das passagens, trilhas, rotas e estradas, lugares para uso didático, descanso e contemplação com bancos; (i) sinalização de trânsito nas rotas, no caminho e na estrada; é intenso o movimento de motos, carros, caminhões com entregas de mercadorias e abastecimento de água, ônibus e vans escolar, ciclistas e pedestres, cCorreios, mães levando e buscando crianças. Tudo isso ocorre no entre turno: saída do matutino, 12h20min, e entrada do vespertino, às 13h30min (Imagem 1, p. 38).

A área verde exposta vai sendo apropriada mais ou menos de acordo com a expansão e ocupação discente em diversificadas situações, com necessidades para convívio social ou a aprendizagem.

Como área de escape ao cotidiano didático indoor (salas de aula), as áreas verdes podem estimular e qualificar um ensino sem fronteiras rígidas, fortalecido pela pedagogia ambiental na construção de setores aprazíveis e edílicos, capazes de desvendar a inibição da criança, elevar a capacidade de suportar exigências de transformação comportamental e aumentar a capacidade mental cognitiva em contato com a natureza.

A área verde de uma escola é mais que uma designação, é um projeto sempre em expansão que pode se destacar pela afetividade simbólica configurada pelas ausências ou inacabamentos. As áreas livres verdes não é a determinação de um espaço mensurável, necessário ao próprio ato de projetar potencialidades didáticas, elas são, quem sabe, desvios ou caminhos abertos a serem afirmados na pedagogia.

Finalizando, como toda a área verde setorizada mostra-se extremamente suja (Imagem 6, p. 47 e Ficha de Informação - Tabela 1, p. 47), inicialmente, a manutenção da limpeza no local, e tão somente essa, pode indicar esforços aos projetos escolares focados na Educação Ambiental quanto ao comportamento pessoa-ambiente. Isso é a acuidade no bem-estar da comunidade, buscando com a própria população carinho e zelo, promovendo diversas formas de sentimentos para o uso que reflita no próprio benefício à integração homem e natureza em espaços educativos, o além-sala de aula. Assim foi essa dissertação, estilo comunicação \& prosa. 


\section{REFERÊNCIAS}

ANDRADE, Mário. De pauliceia desvairada a café (poesias completas). São Paulo: Círculo do Livro, 1986.

ARAGOnÉS, J. I. Cognición Ambiental. In: ARAGONÉS, J.I.; AMÉRICO, M. (Org.). Psicologia ambiental. Madri: Pirámide, 2002.

ARANTES, Valéria Amorim; MACEDO, Lino de; MACHADO, Nilson José. Jogo e projeto: ponto e contraponto. São Paulo: Summus, 2006.

AZEVEDO, Giselle Arteiro Nielsen. Arquitetura escolar e educação: um modelo conceitual de abordagem interacionista. Rio de Janeiro. 2002. 208 p. Tese de Doutorado. Universidade Federal do Rio de Janeiro. Rio de Janeiro, 2002. (COPPE/UFRJ, D. Sc., Engenheria de Produção).

BARDIN, Lawrence. Análise de conteúdo. São Paulo: Edições 70, 2011.

BEGOSSI, Alpina. Ecologia humana: um enfoque das relações homem-ambiente. Interciência 18(1): 121-132. Disponível em: <http://wwww.interciencia.or.ve1993>. Acesso em: 21 de nov 2015.

BLANCHARD-LAVILLE, Claudine. Os professores entre o prazer e o sofrimento. São Paulo: Loyola, 2005.

BOMFIM, Zulmira Áurea Cruz. Afetividade e ambiente urbano: uma proposta metodológica pelos mapas afetivos. In: GÜNTHER, Hartmut; PINHEIRO, José Q (Org.). Métodos de pesquisa nos estudos pessoa-ambiente. 1. ed. São Paulo: Casa do psicólogo, 2008.

BONDUKI, N. G. Habitação e Urbanismo. In: SZMRECSSÁNYI, Tomás. (Org.). História econômica da cidade de são paulo. São Paulo: Globo, 2004.

BRASIL. Ministério da Educação (MEC). Secretaria de Educação Básica. Parâmetros nacionais de qualidade para a educação infantil. vol. 1 Brasília: MECISEB, 2006. Disponível em: <http:porta.mec.gov.br/seb/arquivo/pdf/volume2.pdf>. Acesso em: 3 dez. 2014.

BRASIL. Ministério da Educação (MEC). Secretaria de Educação Básica. Secretaria de Educação a Distância. Livro de estudo: módulo III. vol. 7. Brasília: 2006. 12 p.

BRASIL. Ministério da Educação (MEC). Territórios educativos para a educação integral - Caderno Mais educação. Secretaria de Educação Básica. Ministério da Educação. Disponível em: <portal.mec.gov.br/seb>. Acesso em: 3 dez. 2014.

BRASIL. Ministério da Educação. MEC. Secretaria de Educação Básica. Parâmetros básicos de infraestrutura para instituições de educação infantil. Brasília: MEC, SEB, 2006. Disponível em: 〈http://portal.mec.gov.br/seb/arquivos/pdf/Educinf/miolo_infraestr.pdf> Acesso em: 21 nov. 2014. 
BRASIL. Ministério da Educação. MEC. Secretaria de Educação Fundamental. Parâmetros curriculares nacionais: apresentação dos temas transversais, meio ambiente. Secretaria de Educação Fundamental. - Brasília: MEC/SEF, 1997. 146 p.

Brasil. Ministério da Educação. Secretaria de Educação Básica. Secretaria de educação continuada, alfabetização, diversidade e inclusão. Secretaria de Educação Profissional e Tecnológica. Conselho Nacional da Educação. Câmara Nacional de Educação Básica. Diretrizes Curriculares Nacionais Gerais da Educação Básica. Secretaria de Educação Básica. Diretoria de Currículos e Educação Integral. Brasília: MEC, SEB, DICEI, 2013. 562p.ISBN: 978-857783-136-4

BRONFENBRENNER, Urie. A ecologia do desenvolvimento humano: experimentos naturais e planejados. Porto Alegre: Artes Médicas, 1996.

CALLEJAS, Ivan Júlio Apolônio et al. Diversidade e índices arbóreos em ambientes escolares. Revista do Centro de Ciências Naturais e Exatas - UFSM, Santa Maria. Revista Eletrônica em Gestão, Educação e Tecnologia Ambiental - REGETe-ISSN 22361170 - V. 18 n. 1 Abr 2014, p. 454-466. Disponível em: <http://dx.doi.org/10.5902/2236117012537> Acesso em: 21 nov. 2014.

CAMPOS-DE-CARVALHO, Mara. A Metodologia do Experimento Ecologico. In: GÜNTHER, Hartmut; PINHEIRO, José Q (Org.). Métodos de pesquisa nos estudos pessoa-ambiente. 1. ed. São Paulo: Casa do psicólogo, 2008.

CARPINTEIRO, Antonio Carlos. Teorias do espaço escolar. Brasília: Universidade de Brasília, 2008.

CARVALHO, I. C. M. Educação ambiental: a formação do sujeito ecológico. 6. ed. São Paulo: Cortez, 2012.

CAVALCANTE, Sylvia; ELALI, Gleice A. (Org.). Temas básicos em psicologia ambiental. Petrópolis, RJ: Vozes, 2011.

CHAUÍ, Marilena. Introdução à historia da filosofia: dos pré-socráticos a aristóteles. São Paulo: Companhia da Letras, 2002.

DADVAND et al. 2015. Proceeding of the National Academy of Sciences o estudo Green spaces and cognitive development in primary schoolchildrens. Disponível em:< file:///C:/Users/Jo\%C3\%A3oFernando/Documents/Barcelona\%20Areas\%20verdes\%20menta $1 \% 20$ PNAS-2015-Dadvand-7937-42.pdf.>. Acesso em: 6 fev. 2016.

MACIEL, Regina Heloisa. Método de avaliação da percepção ambiental. In: GÜNTHER, Hartmut; PINHEIRO, José Q (Org.). Métodos de pesquisa nos estudos pessoa-ambiente. 1. ed. São Paulo: Casa do Psicólogo, 2008.

CASTELLAR, Sonia M. Vanzella; MUNHOZ, Gislaine Batista. Conhecimentos escolares e caminhos metodológicos. São Paulo: Xamã, 2012.

CRESWELL, John W. Projeto de pesquisa, método qualitativo, quantitativo e misto. 3. ed. - Porto Alegre: Artmed, 2010. 
CULLEN, Gordon. Paisagem Urbana. 1971. Dispoíivel em: http://pt.slideshare.net/ARQ210AN/paisagem-urbana. Acesso em: 2 fev. 2016.

DIAS, Genebaldo. F. Educação ambiental: princípios e práticas. 9. ed. São Paulo: Gaia, 2004.

DOWNS, Roger M. Maps in minds. NY: Harper \& Row, 1977.

ECO, Humberto. Como se faz uma tese. São Paulo: Perspectiva, 2006.

ELALI, Gleice Azambuja, PINHEIRO, Jose Q. FERNANDES, Odara S. Observando a Interação Pessoa-Ambiente: Vestígios Ambientais e Mapeamento Comportamental. In: GÜNTHER, Hartmut; PINHEIRO, José Q (Org.). Métodos de pesquisa nos estudos pessoa-ambiente. 1. ed. São Paulo: Casa do Psicólogo, 2008.

ELALI. Gleice Azambuja. O ambiente da escola - o ambiente na escola: uma discussão sobre a relação escola-natureza em educação infantil. Estudos de psicologia 2003, 8(2), 309319. Disponível em: <www.scielo.br_pdf_epsic_v8n2_19047>. Acesso em 19 set. 2014.

FEDRIZZI, B. A. Organização em pátios escolares grandes e pequenos. In: V. Del Rio, C. R. Duarte \& P. A. Rheingganztz (Org.) Projeto do lugar: colaboração entre Psicologia, Arquitetura e Urbanismo. Rio de Janeiro: Contra Capa Livraria, 2002.

FERREIRA, Ainda Maria de Figueiredo. Interação criança-espaço exterior em jardim de infância.Tese de Doutorado em 2015. Universidade de Aveiros - Departamento de Educação,Portugal. Disponível em: <http://ria.ua.pt/bitstream/10773/14081/1/intera\%C3\%A $7 \% \mathrm{C} 3 \% \mathrm{~A} 3 \mathrm{o} \% 20$ crian\%C3\%A7aespa $\% \mathrm{C} 3 \% \mathrm{~A} 7 \mathrm{o} \% 20 \mathrm{exterior} \% 20 \mathrm{em} \% 20 \mathrm{jardim} \% 20 \mathrm{de} \% 20 \mathrm{i}$ nfancia.pdf >. Acesso em: 6 fev. 2016.

FRAGO, Antonio Viña; ESCOLANO, Augustin. Currículo, espaço e subjetividade: a arquitetura como programa. Rio de Janeiro: DP\&A, 1998.

FUNDAÇÃO PARA O DESENVOLVIMENTO DA EDUCAÇÃO. Arquitetura escolar paulista. São Paulo: FDE, 2006, 4 vols.

FDE, 1997.

Escolas estaduais de 1. Grau: projeto arquitetônico 96/97. São Paulo:

FREIRE, Paulo. A educação na cidade. São Paulo: Cortez, 1994.

Pedagogia do oprimido. Rio de Janeiro: Paz e Terra, 1974

FROEBEL, Friedrich W. A. A educação do homem: trad. de Maria Helena Camara Bastos. Passo Fundo: UPF, 2001. 238p.

FLORIANI, D. Dialogos Interdisciplinares para uma agenda socioambiental: breve inventario do debate sobre ciência, sociedade e natureza. In: Desenvolvimmiento e meio ambiente: teoria e metodologia em meio ambiente e desenvolvimento. Curitiba-Paraná, UFPR, 2000. N. 1.

GADOTTI, Moacir. Boniteza de um sonho: ensinar-e-aprender com sentido. São Paulo: Instituto Paulo Freire, 2008. 
GARCIA, E. B. Ação cultural, espaços lúdicos e brinquedos interativos. In: D. S. Miranda (Org.). O parque e a arquitetura: uma proposta lúdica. São Paulo: Papirus, 1996.

GASPARIN, João Luiz. Carta capital. Disponível em: <http://www.cartacapital.com.br/educ acao/carta-fundamental-arquivo/o-pai-da-didatica $\geq$. Acesso em: 20 mar. 2016.

GIBSON, James J. La percepción del mundo visual. Buenos Aires: Ediciones Infinito, 1974.

GINER, De Los Rios F. Grupos escolares. In: Obras completas. Madrid: Espasa-Calpe, 1933

GÜNTHER, Hartmut; PINHEIRO, José Q (Org.). Métodos de pesquisa nos estudos pessoaambiente. 1. ed. São Paulo: Casa do psicólogo, 2008.

GUTIÉRREZ, Francisco; PRADO, Cruz. Ecopedagogia e cidadania planetária. São Paulo: Cortez, 2008.

HELLER, Agnes. O cotidiano e a história. São Paulo: Paz e Terra, 2008.

HIGUCHI, Maria Inês G.; KUHEN, Ariane; BOMFIM, Zulmira A. C. Cognição ambiental. In: CAVAlCANTE, Sylvia; ELALI, Gleice A (Org.). Temas básicos em psicologia ambiental. Petrópolis, RJ: Vozes, 2011.

HORTÈLIO, Lydia. Registro fotográfico: história de uma manhã. 1. ed. Salvador: Massao Ohno Editor, 1987.

HONNEF, Klaus. Pop art. TASCHEN publicações. Colónia: Uta Grosenikn, 2004. Trad. Constança Paiva Boleó Santana (Vernáculo, Ltda.), Lisboa.

HOSSNE, Saad William; FILHO, Jose Marques. Albert Schweitzer e a filosofia da ética de respeito à vida. Revista - Centro Universitário São Camilo - 2013;7(2):206-210 ENSAIO / ESSAY. Disponível em: <http://www.saocamilo-sp.br/pdf/bioethikos/103/8.pdf >. Acesso em: 27 de maio 2015

KISHIMOTO, Tizuko M. A pré-escola em São Paulo. (1877 a 1940). São Paulo: Loyola, 1988.

KOWALTOWSKI, Doris C. C. K. Arquitetura escolar: o projeto do ambiente de ensino. São Paulo: Oficina de Textos, 2011.

KUHNEN, Ariane. Percepção ambiental. In: CAVALCANTE, Sylvia; ELALI, Gleice A (Orgs.). Temas básicos em psicologia ambiental. Petrópolis, RJ: Vozes, 2011.

LIMA, Mayumi Souza. A cidade e a criança. São Paulo: Nobel, 1989.

LINCH, Kevin. A imagem da cidade. Lisboa: Edições 70. 1954. Disponível em: <http://www .tudosobrearquitetura.com.br/2014/04/download-livro-imagem-da-cidadekevin.html>. Acesso em: 12 dez. 2014.

MOREIRA, Marco Antonio. Aprendizagem significativa subversiva. Publicada também em Indivisa. In: III Encontro internacional sobre aprendizagem significativa. 2000, Lisboa, Boletín de Estúdios e Investigación, n. ${ }^{\circ}$ 6, p. 83-101, 2005. 2. ed. 2010; ISBN 85-904420-71. 
MORIN, Edgar. Os sete saberes necessários à educação do futuro. 9. ed. São Paulo: Cortez, 2004.

NOVA enclícica do papa Francisco pede conversão ecológica. CNBB on-line, São Paulo, 14 ago. 2015. Disponível em :<CNBB-http://www.cnbb.org.br/imprensa-1/internacional/16727nova-enciclica-do-papafrancisco-pede-conversao-ecologica $>$. Acesso em: 14 ago. 2015

NOVA ESCOLA. Grandes pensadores. v. 2, n. 10, ago. 2006. São Paulo: Abril, ISSN 0103-0116. E.

OLIVEIRA, N. C. Evolução e flexibilidade da arquitetura escolar. In: Fundação para o Desenvolvimento da Educação (Org.) Arquitetura escolar e política educacional: os programas na atual administração do estado. São Paulo: FDE 1998.

PATO, Claudia Marcia Lyra. Valores ecológicos. In: CAVALCANTE, Sylvia; ELALI, Gleice A. (Orgs.). Temas básicos em psicologia ambiental. Petrópolis, RJ: Vozes, 2011.

. Comportamento ecológico: relações com valores pessoais e crenças ambientais. Tese de Doutorado do Instituto de Psicologia da Universidade de Brasília. Brasília 2004.

PIAGET, Jean. Epistemologia genética. São Paulo: Abril Cultural, 1983.

PINHEIRO, Q. José; ELALI, Glaice A.; AZEVEDO, Andreia V. M; FARIAS, Barbara C. G.COSTA; ANDRADE, Mariana C. Y; S. Soraya. Diário pessoal como técnica de coleta de dados em estudos sobre as relaçoes pessoa-ambiente. In: GÜNTHER, Hartmut; PINHEIRO, José Q (Org.). Métodos de pesquisa nos estudos pessoa-ambiente. 1. ed. São Paulo: Casa do psicólogo, 2008.

POLLARD, M. Maria Montessori. Coleção personagens que mudaram o mundo: grandes humanistas. Porto Alegre: Globo, 1993.

POMPÉIA, Raul. O ateneu.16. ed., São Paulo: Ática, 1996.

PRESCOTT, E. The enviromenment as organizer of intente in child-care. In C. Weinstein \& T. Davis (Org.) Spaces for children: the built environment and child development. Nova York: Plenum, 1987.

RIO, Vicente Del. Cidade da mente, cidade real. Percepção ambiental e revitalização na área portuária do Rio de Janeiro. In: DEL RIO, V; OLIVEIRA, L. (Org.). Percepção ambiental: a experiência brasileira. São Paulo: Universidade de São Carlos. Studio Nobel, 1996.

RONDON, Cintia Ribeiro. Pátios invisíveis: a dimensão do verde na educação infantil. Dissertação de mestrado em Arquitetura e Urbanismo. Universidade Presbiteriana Mackenzie. São Paulo, 2014

SAGER, Fabio. O significado do espaço físico da escola infantil: uma abordagem das representações sociais do lugar. Tese de Doutorado. Universidade federal do Rio Grande do Sul. Instituto de Psicologia - Programa de pós-Graduação. Dez. 2002.

SATO, Michele e Isabel Cristina Moura Carvalho (Org.). Educação ambiental: pesquisa e desafios. Porto Alegre: Artmed, 2005. 
SEGAWA, Hugo. Hélio Duarte moderno, peregrino, educador. arquitetura e urbanismo. São Paulo, n. ${ }^{\circ}$ 80, ano 14, p. 59-65, out./nov. 1998.

SEIXAS, Alexandre Rodrigues. A arquitetura escolar de vilanova artigas e carlos cascaldi (1959 - 1962). São Carlos, Escola de Engenharia de São Carlos da Universidade de São Paulo, 2002.

TEIXEIRA, Anísio. Um presságio de progresso. N. ${ }^{\circ}$ 4, set-dez. São Paulo: Habitat, 1951. Acervo FAU-USP.

TIRIBA, Leia. Educação e vivência do espaço: diálogo entre a arquitetura e a pedagogia. Salto para o futuro. V. 04, 2008.

TUAN, Yi-Fu. Espaço e lugar: a perspectiva da experiência. Londrina: Eduel, 2013.

Topofilia: um estudo da percepção, atitudes e valores do meio ambiente. Londrina: Eduel, 2012. 


\section{APÊNDICE}

\section{APÊNDICE A}

\section{ROTEIRO DE ENTREVISTA}

Conversa com propósito referente ao discurso do lugar centrado na temática da pessoa, do ambiente ou na relação (DAWNS, 1977; ELALI, 2003; GIBSON, 1974; GUNTHER, 2008; RIO, 1996; TUAN, 2013).

Bom dia/boa tarde!!!

Pedimos a gentileza de responderem.

1 Se lhe fosse entregue um mapa cartográfico para facilitar uma visita não guiada na Escola Estadual Professora Phylomena Baylão, você dividiria a área escolar em quantos setores? Vocês podem fazer isso agora? Enumere os setores onde parte em sistemas de valores perceptivos de opinião ao lugar: do positivo de aconchego (agradabilidade) indo ao negativo, desagradável (insegurança) Escala Likert $(+3+2+10-1-2-3)$. Escolha três setores para uma visita guiada por você?

2 Agora, cita as sensações que teria um cidadão comum visitando às áreas externas por você identificadas?

\section{\begin{tabular}{|l|l} 
Setores $1 \ldots$ & Transcrever a fala gravada.
\end{tabular}}

3 O que causaria maior(es) impressão(ões) nesse cidadão e como ele reagiria nesse setor?

\begin{tabular}{|l|l} 
Setores $1 \ldots$ & Transcrever a fala gravada.
\end{tabular}

4 Você pode fotografar uma referência de relevância existente. Algum marco, um local ou símbolo de representatividade que você avalie como importante nesse setor?

\begin{tabular}{|l|l|} 
Setores $1 \ldots$ & Transcrever a fala gravada.
\end{tabular}

5 Em algum desses setores, há uso de prática didática em experiência cotidiana além-sala de aula? Identifique no mapa.

6 Caso as áreas verdes livres da escola fossem um semáforo a sua frente para o uso do ensino aprendizado em situação de transferência didática transdisciplinar, qual fase estaria acesa?

7 Agora, para finalizar, indique três setores no mapa, por desejo de escolha, que podem, ordenadamente, ser geradores de atividades dirigidas em prática ao ensino aprendizado além sala de aula.

\begin{tabular}{|l|l|}
\hline Setor de desejo & Transcrição da fala \\
\hline & \\
\hline & \\
\hline & \\
\hline
\end{tabular}

Obrigado, Bom dia/boa tarde! 


\section{APÊNDICE B}

FICHA DE IDENTIFICAÇÃO

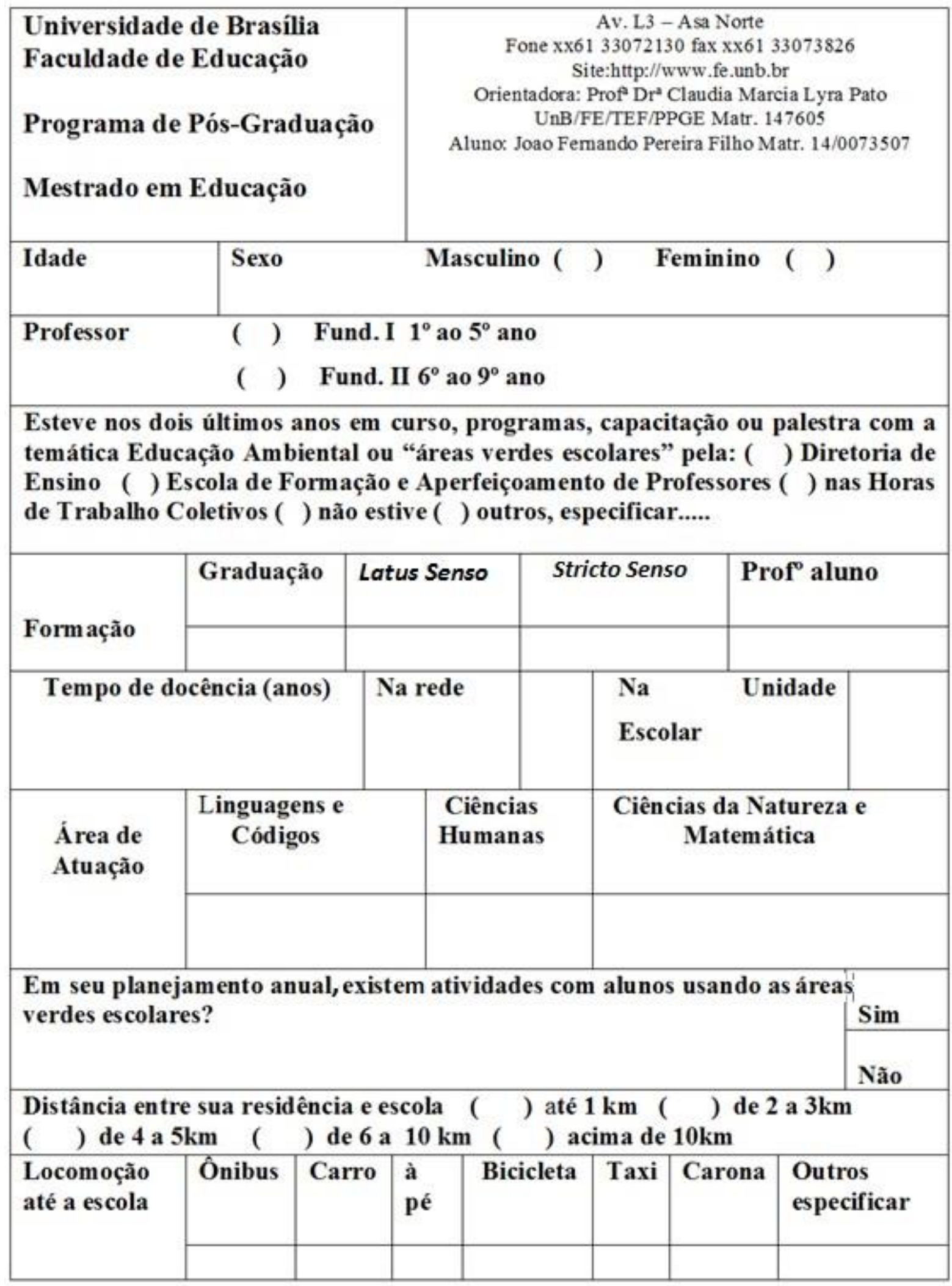




\section{ANEXOS}

\section{ANEXO 1}

\section{GOVERNO DO ESTADO DE SÃO PAULO SECRETARIA DE ESTADO DA EDUCAÇÃO Diretoria de Ensino Região Norte 2}

Rua Plinio Pasqui, 217 - Parada Inglesa 02244030 São Paulo/SP

(11) 22097300 dent2@see.sp.gov

\section{MEMORANDO DE AUTORIZAÇÃO DE PESQUISA / SEE-SP}

Memorando $n^{\mathbf{o}}$

São Paulo, de de 2015 .

Autorizamos o Sr. João Fernando Pereira Filho aluno do Mestrado de Educação Ambiental, da Universidade de Brasília - UnB, a realizar pesquisa nessa Instituição de Ensino. Participarão da pesquisa professores da rede pública de ensino que desenvolvam atividades de ensino aprendizagem em diversas áreas do saber com práticas docentes em sala de aula.

Informo que o projeto de estudo foi analisado, estando em conformidade com as normas da Secretaria Estadual da Educação do Estado de São Paulo.

Atenciosamente,

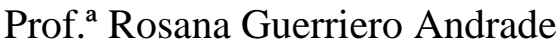

Dirigente Regional de Ensino Norte 2 


\title{
ANEXO 2
}

\section{TERMO DE CONSENTIMENTO LIVRE E ESCLARECIDO ESCLARECIDO}

\author{
Universidade de Brasília \\ Faculdade de Educação \\ Programa de Pós-Graduação \\ Mestrado em Educação
}

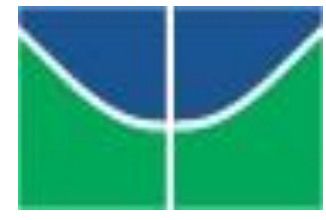

\section{Termo de Consentimento Livre e Esclarecido}

Nome:

$\operatorname{Rg}$

Expedição:

Escola de atuação/ cidade: Escola Estadual Philomena Baylão SP/capital

O presente termo tem como objetivo o convite ao(à) professor(a) acima identificado(a) para participar da pesquisa intitulada Áreas livres: um estudo de percepção dos rofessores sobre as áreas verdes do entorno predial escolar, inserida no Programa de Pós-Graduação da Universidade de Brasília-UnB/Faculdade de Educação, tendo como pesquisador o mestrando João Fernando Pereira Filho, orientando pela Professora Doutora Claudia Marcia Lyra Pato.

O objetivo da pesquisa é um estudo de percepção dos professores sobre as áreas verdes da escola como espaços além-sala de aula para o ensino-aprendizado em uma escola pública estadual pertencente à Diretoria Norte 2 São Paulo/capital. Adotando como uma das estratégias a realização de coleta de dados em método de estudo centrado no ambiente com análise dos dados contidos em instrumentos desenvolvidos na percepção do ambiente nas diferentes áreas do conhecimento.

A sua contribuição consiste em participar de uma pesquisa multifásica em um questionário e oficina pedagógica, em que: a) suas colocações serão tratadas de forma anônima e confidencial; b) os dados obtidos serão utilizados exclusivamente para fins acadêmicos; c) não havendo custo e quaisquer outras compensações financeiras; d) não haverá risco de qualquer natureza relacionada à sua participação; e) o participante poderá obter esclarecimento ou desistir da atividade a qualquer momento sem nenhum prejuízo ou constrangimento.

$$
\begin{aligned}
& \text { (assinatura do pesquisador - João Fernando Pereira Filho) } \\
& \text { Contatos: Tel.: (11) 44854342, e-mail: joaofilhosaopaulo@gmail.com }
\end{aligned}
$$

$\mathrm{Eu}$, tendo em vista os itens apresentados, de forma livre e esclarecida, aceito o convite para participar voluntariamente da pesquisa acima descrita. Recebi uma cópia deste termo de consentimento livre e esclarecido e me foi dada a oportunidade de ler e esclarecer as minhas dúvidas.

São Paulo, de 2015. 
ANEXO 3

\section{TERMO DE COOPERAÇÃO}

Universidade de Brasília

Faculdade de Educação

Programa de Pós-Graduação

Mestrado em Educação

Termo de Cooperação

O presente termo tem como objetivo oficializar o convite à Escola Estadual Philomena Baylão - Diretoria Norte 2 São Paulo/capital - SEE-SP, para participar como instituição parceira da pesquisa intitulada Áreas livres: um estudo de percepção dos professores sobre as áreas verdes do entorno predial escolar, inserida no Programa de Pós-Graduação da Universidade de Brasília-UnB/Faculdade de Educação, tendo como pesquisador o mestrando João Fernando Pereira Filho, orientando pela professora Doutora Claudia Marcia Lyra Pato.

O objetivo da pesquisa é um estudo de percepção dos professores sobre as áreas verdes como espaços além-sala de aula para o ensino-aprendizado em uma escola pública estadual pertencente à Diretoria Norte 2 São Paulo/capital. Adotou-se como estratégias a realização de coleta de dados multifásica em pesquisa/estudo centrado no ambiente com análise nos instrumentos desenvolvidos na percepção do ambiente com a aplicação de entrevistas simultânea a caminhada pelo local, participação de Oficina Pedagógica e resposta ao questionário estruturado. Todos instrumentos com o propósito de identificar fenômeno comportamental de interesse no estabelecer um contato inicial com o local de estudo monitorado por representante da escola.

A participação da Escola Estadual Philomena Baylão consiste em: a) disponibilizar território de pesquisa que propicie informações no que se refere à percepção dos atores envolvidos diante as áreas verdes da escola; b) contribuir com a participação nas atividades desenvolvidas; e c) contribuir em construção coletiva do conhecimento e análise da realidade com confronto e troca de experiências, composto de sensibilização, compreensão, reflexão das áreas externas.

Será garantido o anonimato dos participantes da pesquisa, sendo que qualquer identificação somente será feita mediante expressa autorização destes. Fica também feito o compromisso de que os dados dos professores disponibilizados pela Escola Estadual Philomena Baylão serão utilizados única e exclusivamente para fins relacionados a esta pesquisa e resguardado o devido sigilo. O caráter voluntário da participação dos professores garante a instituição avaliar as situações especificas de sua contribuição que certifique a prevenção de eventuais prejuízos.

$\mathrm{Eu}$,

Diretora da Escola Estadual Philomena Baylão, li o presente termo e aceito o convite para que essa instituição da pesquisa acima descrita, em forma de parceria, contribuindo para que as estratégias de coleta de dados possam ser viabilizadas com vistas ao alcance dos seus objetivos.

São Paulo, de 2015 . 